OPEN ACCESS

Citation: Davide Angelucci, Lorenzo De Sio (2021) Issue characterization of electoral change (and how recent elections in Western Europe were won on economic issues). Quaderni dell'Osservatorio elettorale - Italian Journal of Electoral Studies 84(1): 45-67. doi: $10.36253 /$ qoe-10836

Received: May 1, 2021

Accepted: June 9, 2021

Published: July 20, 2021

Copyright: @2021 DavideAngelucci, Lorenzo De Sio. This is an open access, peer-reviewed article published by Firenze University Press (http://www. fupress.com/qoe) and distributed under the terms of the Creative Commons Attribution License, which permits unrestricted use, distribution, and reproduction in any medium, provided the original author and source are credited.

Data Availability Statement: All relevant data are within the paper and its Supporting Information files.

Competing Interests: The Author(s) declare(s) no conflict of interest.

\section{Issue characterization of electoral change (and how recent elections in Western Europe were won on economic issues)}

\author{
Davide Angelucci ${ }^{1}$, Lorenzo De SiO ${ }^{2, *}$ \\ ${ }^{1}$ Italian Center for Electoral Studies (CISE), Luiss University, Rome, 0000-0002-6695-1605 \\ ${ }^{2}$ Italian Center for Electoral Studies (CISE), Luiss University, Rome, 0000-0003-0814-6744 \\ ${ }^{*}$ Corresponding author. E-mail: ldesio@luiss.it
}

\begin{abstract}
Results of the last electoral season in Western Europe have been mostly seen in the light of the success of challenger, anti-establishment parties. According to this narrative, past elections have been overwhelmingly dominated by cultural issues such as immigration and the EU. However, these accounts suffer from several limitations. First, they generally focus on the determinants of the static component of electoral results (i.e. vote choice) rather than the factors leading to vote change (i.e. the individual-level component of aggregate electoral change). Second, relying on party manifestos and programmatic platforms, they usually offer a party-based reconstruction of the general climate of elections. As a consequence, they provide only an indirect, at best limited, overview of the actual political issues that might have driven electoral results. To overcome these limitations, in this paper we introduce a new methodological strategy to characterize electoral results in comparative perspective. To do so we leverage an issue-rich public opinion dataset to estimate individual-level vote change towards each party as a function of issue-based party-voter affinity measures in 6 European countries. Relying on 38 logistic regression models (one for each party), our results contradict many current interpretations of electoral results in Western Europe, in fact showing that economic issues, rather than broad cultural ones, emerged as the most relevant predictors of vote inflows. Furthermore, it also demonstrates the relevance of "cross-ideological" mobilization across all the 6 countries covered in this study.
\end{abstract}

Keywords: electoral change, electoral results, issue politics, economic issues, cultural issues.

\section{INTRODUCTION}

Social science, and political science perhaps even more, is characterized by its inevitable engagement with different audiences. Results of social science are first and foremost aimed to their scientific community; but another often relevant audience is also a broader cultural community (politicians, the media, active citizens) looking at social science for empirical knowledge and interpretations of social reality, with arguments that often become relevant in the public debate (Pizzorno 1993, 31). This is obviously the case for elec- 
tion studies, particularly at the occasion of general elections. In this regard, elections not only perform their basic democratic function of allowing the formation of governments that inherently respond and correspond to citizen preferences (Dahl 1971; Thomassen 2005; Mair 2013), but also represent key occasions where actors involved in the public debate are offered the possibility of gauging actual citizen preferences, in a more reliable and representative way than offered by poll-based public opinion analyses. As a result, the immediate aftermath of a general election is usually characterized, on the media, by intense debates - often fuelled by empirical analyses - about the interpretation of the election result. This is a process we might identify as the characterization of election results, i.e. a collective construction of a (relatively shared) general interpretation of the election outcome: starting from the relatively easy identification of winners and losers (perhaps less easy, when drilling down to geographical disaggregation of results), up to most importantly - the identification of a more general "popular will" emerging from the vote. All this process revolves around the answer to a key, but often understudied, question: what were the elections about (Shamir and Shamir 2008)?

In this regard, the term interpretation appears particularly appropriate. While relatively simple statistical analyses usually allow to identify winners and losers of an election, it is much harder to identify a general "popular will" from an election result. The reason is simple: while e.g. in referenda voters are called to express themselves on actual policy choices, elections see them casting votes to parties that take positions on dozens of different issues, so that it is not easy to identify which actual issue stance determined the fortune of a particular party. And the actual information available for this interpretation is mostly indirect: party platforms, election campaigns, exit-polls estimating the behaviour of particular social groups; geographical results providing more suggestions about the behaviour of the same groups; perhaps even ecological-inference-based estimates of vote turnover tables that try to reconstruct which winning parties attracted votes from which losing parties (albeit both these latter are always prone to even severe ecological fallacy). None of these pieces of information in fact includes direct information about issue determinants of election results. Even when extensive survey data are available (but often not immediately after the election), these frequently only include a relatively limited set of items measuring voter attitudes on few specific policy issues. As a consequence, all these pieces of information only allow a quite indirect, at best limited reconstruction of the actual political issues that might have driven the election result, so that in fact little can be reliably known about actual citizen preferences which, in principle, represent the very core of democratic representation.

Such limited-information reconstruction is vulnerable to a number of biases (even more, when attempted in comparative perspective). To begin with, issue drivers of electoral change are oftentimes indirectly inferred from party platforms and campaigns of winning parties, while in fact there is little guarantee that the actual drivers correspond to the most defining (or visible) campaign issues of each party. And in comparative perspective, commentators often employ even stronger simplifications, by lumping together (based on party families) parties that in fact might even be significantly different in terms of party platforms, not to mention the actual issue drivers of their success.

This paper introduces a novel methodology for characterizing electoral results which, in our view, represents a significant improvement in this regard. In general terms, our proposal consists of three key choices: (a) use of issue-rich public opinion data; (b) focus on issue-related predictors, and in particular on issue-based party-voter affinity measures; (c) focus on vote change (rather than on vote choice) as the outcome to be modelled. By modelling, for general elections, individual vote change (i.e. the individual-level component of aggregate electoral change) through issue-related predictors, we in fact are able to identify the key issues that produced electoral change for each party (and thus for the whole party system), providing an effective issue characterization of electoral change that provides substantive (and potentially unbiased) information about the citizens preferences that drove such change.

We apply this methodology to general elections in six Western European countries in 2017-18 (Austria, France, Germany, Italy, Netherlands, UK), relying on survey data from the ICCP - Issue Competition Comparative Project (De Sio et al. 2019; De Sio and Lachat 2020a); thus, we not only demonstrate our methodology's ability to issue-characterize a single election, but exemplify its ability to support a broader issue characterization of an electoral season across multiple countries. And our results confirm the relevance of our methodology, with findings partly in contrast with most extant literature relying on a party-based characterization of the same elections. While such party-based characterization has so far emphasized the emergence (and key relevance) of a transnational, cultural "cleavage" in Western Europe in recent years, our issue characterization of the same elections suggests an enduring relevance of economic issues, along with diverse non-eco- 
nomic, "cultural" issues, which however are only marginally related to a broader transnational conflict (e.g. over EU integration); and - most importantly - which do not appear to cluster together (in a consistent overarching dimension) in their predictive ability of individual-level vote change.

The paper is organized as follows. After this introductory section, we discuss the main purpose of this paper, introducing the relevance of issue characterization of an election. We then review existing literature to set out theoretical expectations for issue characterization of the elections under study, following then two sections describing our novel method, research design, data and empirical strategy. Presentation and discussion of findings are then offered, followed by conclusions.

\section{CHARACTERIZING ELECTION RESULTS}

Virtually all citizens of any democratic country will have experienced the media coverage and citizen reactions that immediately follow a general election. This is not simply because of the ritual importance of elections as the key process of democracy (such that non-democratic regimes rely on elections to claim democratic status: see e.g. Zakaria 1997), but most importantly because elections, among their many other functions, represent the fundamental occasion for ascertaining citizen preferences on issues facing the future government. It is needless to say that the very core of democracy lies precisely in its ability to provide governments that respond (and corresponds) to these citizen preferences (in fact through the "party government" model: see Thomassen 2005; and Mair 2013 for its crisis). ${ }^{1}$ Hence it is not surprising that, in the immediate aftermath of the election, politicians, commentators, the media, and citizens themselves (e.g. on the social media) all engage in a public discussion towards a shared interpretation of the election result, ultimately aimed at identifying some kind of "popular will" (i.e. citizen preferences) emerging from the result (Hershey 1992). We call this process characterization of the electoral result; a process which in principle should strive for a genuine issue characterization, where actual citizen preferences (key for democratic responsiveness) are somehow ascertained.

Most scholars will have experienced how their contribution to this process is relatively marginal, compared to that of political commentators and the media (Gelman and King 1993; Hale 1993; Hershey 1992; Shamir

\footnotetext{
${ }^{1}$ Albeit of course while preserving the rule of law and fundamental rights and liberties, so that responsiveness will be also possible in the future (Dahl 1971).
}

and Shamir 2008). This is not surprising, considering that: (a) serious scholars usually only make claims based on empirical material that properly justifies such claims; and (b) empirical material available in the immediate aftermath of an election usually hardly justifies specific claims on citizen preferences emerging from the electoral result. In fact, such material mostly consists of three types of sources: aggregate official electoral results; polls (and exit-polls); party platforms and campaign information. From these materials, typical post-election comments and analyses usually include:

a) identification of winners and losers (and of gaining and losing parties) on nationwide aggregate totals (and in terms of seats);

b) analyses of geographically disaggregated results, aiming to infer (from geographical patterns) party choices of particular social groups (and these analyses are extremely vulnerable to ecological fallacy: see King 1997);

c) (where very low level, polling station data are available), estimations (through ecological inference methods) of vote transition matrices, describing vote flows among parties from the previous to the current election; ${ }^{2}$

d) poll and exit-poll data: being usually restricted (for cost reasons) to few items on socio-demographics and vote intentions, these mostly provide no more information than the party choices of specific sociodemographic groups.

This should clarify the problem. Except for the case of referenda, where actual policy choices are at stake, ${ }^{3}$ none of the above empirical materials really allows a direct issue characterization of the result. In fact, what takes place is an indirect, tentative process of issue characterization, which however cannot identify with great precision the actual issue drivers of a party's success. This process in fact is a party-based process of characterization: to infer some issue information, winning (and losing) parties are first identified with their party platforms. Considering that party platforms include dozens of issues, usually commentators focus on a selection of issues which they deem having been particularly impor-

\footnotetext{
${ }^{2}$ Italy developed a venerable tradition in this regard, due to the availability of polling station data and to the early development of appropriate techniques (Barbagli et al. 1979; Corbetta and Schadee 1984; Corbetta, Parisi, and Schadee 1988; Mannheimer 1993; De Sio 2008).

${ }^{3}$ And even in this case, sometimes referendum results might not so obviously reveal citizen policy preferences. Research on the Italian 2016 constitutional referendum clearly showed the effect of referendum politicization on the final outcome, with a sizable group of voters appreciating the referendum proposals but voting "No" as a result of referendum politicization by the then prime minister Matteo Renzi (e.g., Ceccarini and Bordignon 2017).
} 
tant in the campaign; and sometimes data about the behaviour of specific social groups (see above) helps supporting some of these issue characterizations. However, this process is clearly indirect, and potentially vulnerable to a number of biases. First, because political commentators (and politicians) in fact inevitably highlight as key drivers of electoral success those issues that resonate with their political stances (Hershey 1992); secondly, there is even no guarantee that the issues stressed most by a party campaign were in fact the real drivers of the party's success.

Regarding the contributions of social science scholars, even these are often unable to provide a clear and reliable issue characterization of an electoral outcome, due to methodological choices and practical constraints.

First and foremost, comparative analyses of electoral change often rely on party-based characterizations of the electoral outcome, meaning that change is seen in terms of the emergence of new parties (and party families), focusing on their strategies and entrepreneurial efforts. This is for example apparent in the literature about the emergence of new cleavages which cross-cut the traditional left-right dimension of political competition (Hooghe and Marks 2018; Hooghe, Marks, and Wilson 2002; Kriesi et al. 2006, 2008) and the success of challenger parties (de Vries and Hobolt 2020).

The problem here is that any indirect, party-based issue characterization of an election outcome potentially suffers even severe biases, as a result of the fundamental issue aggregation function of political parties. Mass democracy is unthinkable without political parties (Schattschneider 1942) because one of their main functions is to limit the inconsistencies and disequilibria of democratic representation that emerge in a multidimensional issue space (Condorcet 1785; Arrow 1951). Parties indeed package together positions on many different issues, so that voters are presented with a relatively small set of party choices in a much simplified (ideally unidimensional) party space (Black 1948; Downs 1957). However, this simplification process involves collapsing an enormous amount of issue information into few party choices: as a result, any indirect inference of citizen preferences from these enormously simplified party choices is a potentially dangerous operation, given the number of possible biases in the process. Thus, we argue that any issue characterization of an electoral outcome that only relies on party platforms and party performance should be handled with great caution.

But even research employing survey data usually suffers cost and length constraints that limit the measurement of issue attitudes to an often quite small set of issues, usually meant (again) to act as "representative" issues of a simplified, low-dimension space. A prominent example in this respect is the EU integration issue. As the EU has become an increasingly salient issue, its electoral importance has grown as well (Franklin and Wlezien 1997), with voters casting their votes also on the basis of their preferences about the EU, i.e. EU issue voting (e.g. de Vries 2007, 2010). To analyse this phenomenon, most survey studies have indeed relied on measures that capture respondents' positions on an overarching pro/anti EU dimension, thus focusing on general attitudes towards the integration process, but without specific items concerning the actual content of policies decided at the EU level (Angelucci, De Sio, and Paparo 2020; Weber 2009). And the limitations of this approach become more visible as a by now extensive literature on $\mathrm{EU}$ politicization and EU issue voting suggests that the degree of contentiousness of the EU varies significantly across EU specific policy domains (Angelucci and Isernia 2020; de Wilde, Leupold, and Schmidtke 2016) and that different EU-related policies matter with different importance (and in different directions) for voting behaviour (Angelucci, De Sio, and Paparo 2020). And the problem is even bigger for traditional issue dimensions (such as the classic two-dimensional representation of issue attitudes defined by "economic" and "cultural" issues): campaigns and vote choices are in fact never about such general issue dimensions, which only exist for scholars, so that the (often inevitable) strategy of including, in a survey questionnaire, few items aimed at "sampling" a general issue dimension hardly allows to get a more nuanced issue characterization of the results.

In addition, a large part of research on individuallevel political behaviour mostly focuses on predicting vote choice rather than vote change, so that its ability is mostly in describing the profiles of winning and losing parties (even on specific issues), rather than focusing on which issues drove individual-level change, the mechanism producing aggregate electoral change. ${ }^{4}$

As a result, we mostly lack a rigorous and unbiased possibility for a genuine issue characterization of an electoral outcome. This is unfortunate, as the question is of great relevance for the quality of democratic representation, allowing to clarify what voters want from elected officials the day after the elections (Hershey 1984, 1992).

We now move to proposing a methodology aimed to address this problem, leveraging an exceptionally issue-

\footnotetext{
${ }^{4}$ A notable exception is the literature on economic voting, which - initially only relying on aggregate data, but then increasingly employing individual-level data - has consistently focused on change as the outcome (see e.g. Lewis-Beck and Nadeau 2011, also for a review). However, this has implied restricting the focus to a single issue (the state of the economy), and mostly in a "valence" framework (Stokes 1963).
} 
rich dataset and an innovative model of vote change, allowing to reconstruct a precise issue characterization of an election. However, as we also offer here an example of an empirical application of this novel methodology, we first need to set broad expectations about the key issue drivers of electoral change in the countries and elections we analyse. We do so by briefly reviewing the scientific literature focusing on the turbulent electoral and party system changes that have invested Western Europe in the last decade.

\section{RECENT PARTY DEVELOPMENTS IN WESTERN EUROPE}

Recent years have seen turbulent electoral change. The election of Donald Trump in the US and the Brexit referendum in 2016 are just the most prominent outcomes of a sort of perfect storm (De Sio and Lachat 2020a) in which multiple crises (the financial crisis and, in Europe, the refugee crisis) fuelled the rise of challenger parties throughout the Western world (Kriesi and Schulte-Cloos 2020; Matthijs Rooduijn et al. 2019).

Coming more specifically to Western Europe, the large amount of literature analysing the electoral success of challenger parties both on the right and the left (Kriesi and Schulte-Cloos 2020; Matthijs Rooduijn et al. 2017; Matthijs Rooduijn and Burgoon 2018; de Vries and Hobolt 2020) leaves a still open debate. In particular, with most of this literature focusing on the determinants of vote for radical right and radical left parties, many have argued that while these parties are the expression of a generalised political discontent towards the political establishment, a feature that unites these parties under the "populist" label (Bélanger and Nadeau 2005; Dalton and Weldon 2005; Hooghe and Dassonneville 2018; Ivarsflaten 2008; Pauwels 2014; Werts, Scheepers, and Lubbers 2013), their electoral fortunes do not appear linked to common long-term socio-structural factors (Kriesi and Schulte-Cloos 2020; Matthijs Rooduijn and Burgoon 2018). On the one hand, radical left parties (such as Podemos in Spain or Syriza in Greece) have leveraged economic issues on their opposition towards the capitalist organizations of contemporary societies (March 2013); on the other, radical right parties have instead leveraged an allegedly new demarcation/integration cleavage, not subsumable under the traditional leftright economic division and rather articulated on a cultural dimension (Kriesi et al. 2008).

This new "cleavage" has been labelled in different ways (Bornschier 2010; Hooghe and Marks 2018; Hooghe, Marks, and Wilson 2002; Kriesi et al. 2008; de
Wilde et al. 2019), but authors do agree on both the origins and the electoral implications of its consolidation as a source of political contestation (Kriesi and SchulteCloos 2020). First, this cleavage originated from the widespread consolidation of the globalization process and, in Europe, of the process of EU integration. Both phenomena produced new challenges (e.g. more intense immigration flows) and policy constraints to established political elites, especially in the economic field (Mair 2013). Secondly, all this produced a new social conflict (and new alliances as well) pitting losers against winners of globalization. Thirdly, there is consensus in considering this cleavage articulated, in Europe, on two key issues: immigration and EU integration. The result of these processes has been a reinforcement of the relevance of a cultural dimension within the bidimensional, economic-cultural space that has been documented organizing citizen attitudes in Western Europe for a long time (Middendorp 1978; see also Kitschelt 1994; Hooghe, Marks, and Wilson 2002).

While still acknowledging the relevance of the traditional economic dimension of competition, scholars have also suggested that this new cleavage has probably become the main dimension of political competition in Europe, suggesting that this cultural dimension is key for understanding the success of challenger parties and the recent dynamics of electoral politics. In a recent comparative study across (then) $28 \mathrm{EU}$ countries, Emanuele et al. (2020) found that the demarcation cleavage has been massively politicised throughout Europe, with major exchanges of votes occurring across parties politicizing such demarcation issues. De Vries and Hobolt (2020) also argue that the success of challenger parties (both on the left and the right) should be attributed to their entrepreneurial strategies on new issues (such as immigration, EU integration, and the environment) which do not fit into the traditional economic left-right dimension. Analogously, Green-Pedersen and Otjes (2019) referred to societal organization and immigration as by now key electoral issues. Finally, Norris and Inglehart (2019), following on the seminal study on post-materialism (Inglehart 1977), argue that if the rise of social-liberal values motivates the rise of libertarian populists "when the rising tide of social liberalism among the younger, college-educated population is combined with deep disillusionment with the performance of mainstream political parties and leaders" (Norris and Inglehart 2019, 43), it also spurs the counter-reaction of authoritarian-populist parties and leaders, mobilising voters on culturally conservative and nationalist stances.

In addition, increased relevance of cultural issues on electoral competition has not affected challenger parties 
only: there is evidence of a counter-reaction on the side of mainstream parties (although in a not always certain direction). Several scholars (Abou-Chadi 2016; AbouChadi and Krause 2020; Han 2015; Wagner and Meyer 2017) provided, for example, evidence of contagion effects - on immigration - of radical right parties' positions to mainstream parties; Abou-Chadi and Krause (2020) also showed the relevance of what they call the second (cultural) dimension for social-democratic parties, confirming that mainstream parties too are dragged to compete on the new demarcation cleavage. Carrieri (2020) provides evidence of an integration-side response to the politicization of the demarcation side of the cultural cleavage by challenger parties, showing how Europhile parties in fact reacted to Euroscepticism by mobilising a pro-EU electoral front, and no longer silencing the EU integration issue as previously expected (De Sio, Franklin, and Weber 2016; Hooghe and Marks 2018). Finally, Turnbull-Dugarte (2020) also reports evidence of how the demarcation-side politicization in Germany triggered an integration-side reaction, again supporting the idea that this new cultural dimension of competition is becoming a relevant structuring source of electoral competition (de Vries and Hobolt 2020).

In electoral terms all these dynamics were clearly reflected in a high level of electoral volatility and in the relevance of cultural demarcation parties in driving these shifts (Emanuele, Marino, and Angelucci 2020). On this backdrop, we can advance broad expectations about key predictors of vote change and issue characterization of electoral results. In terms of general propositions, we expect that: (1) change should be dominated by cultural issues, with particular reference to immigration and EU integration, and with a less important role of economic issues, perhaps confined to the radical left or to left-wing populist parties; (2) if the demarcation/ integration cleavage represents a truly new dimension of contestation, then we expect to find that key cultural issue drivers of vote change should cluster together consistently in predicting the electoral fortunes of parties. In other words, we expect that voters' preferences and voter's party evaluations on demarcation policy goals should be consistently combined.

\section{OUR PROPOSAL}

As said previously, we observe that most issue characterization of election outcomes is performed either indirectly (party-based characterization) or relying on an over-simplification of the issue space. We propose instead, based on appropriate and issue-rich data, to perform an actual issue characterization of election outcomes.

In methodological terms, and differently from most past literature, our focus is on the individual-level mechanism behind aggregate electoral change: individual vote shift, i.e. a change in vote choice towards another party. Along with turnout dynamics (also included here, in terms of change from abstention), this is in fact the key mechanism producing electoral success or failure. In particular, we rely on three choices:

a) use of survey data to model voting behaviour at the individual level;

b) focus on issue-related predictors, and in particular on issue-based party-voter affinity measures; this requires using a survey dataset with items concerning a large and comprehensive set of issues, and also including explicit measurement of party-voter issue affinity (see below);

c) focus on vote change (rather than on vote choice) as the outcome to be modelled. By modelling individual vote change (i.e. the individual-level mechanism behind aggregate electoral change) through issuebased party-voter affinities, we are able to identify key issues behind electoral change, providing an effective issue characterization of electoral change that provides substantive (and unbiased) information about those citizen preferences that determined such change, leading to victories and defeats for different parties. Hence, our main dependent variable will be vote choice change, i.e. a change in the voted party compared to the previous election (see the next section).

In particular, our strategy is as follows. Separately for each party, we estimate a model of vote change towards the party (joining the party) based on issuerelated voter-party affinity measures, modelling which issues led voters to join a particular party. We then present results of all these models (in terms of issues that drove change towards each party).

For presentation reasons, we also rank parties on their electoral performance, arranging them along a winner-loser dimension that allows quick identification of issues that drove success of the most important winning parties. However, attraction of new votes is not limited to winning parties: the actual gain or loss balance of a party in fact hides much more complex patterns of inflows and outflows, so that - very often - even overall losing parties still attract inflows, perhaps in specific constituencies. This is why we assess issue predictors of vote inflows for all parties (including overall losing parties). Of course, for losing parties vote inflows will be less important than vote outflows; but - in issue terms - inflows mean that 
perhaps there is some particular issue stance that - while unable to counterbalance the outflows produced by other "losing" issue stances - indeed produced a positive impact, able somehow to limit overall losses.

This ability of modelling the "winning" side even for losing parties, allowing the inclusion of all parties in the analysis, opens up extremely interesting possibilities. On the one hand, this grounds issue characterization of a particular election on a much larger basis of data; on the other hand, this identifies, in general, all issue goals that drove vote inflows to any party, regardless of each party's final winning or losing status. Compared to partybased characterization (which categorically distinguishes between winners and losers, and mechanically identifies entire party platforms as some popular mandate), such issue-based characterization is in fact able to identify "winning" issues even among losing parties; thus providing an effective and unbiased issue characterization of electoral change.

\section{DATA AND METHODS}

We rely on individual-level data from the voter component of the ICCP (Issue Competition Comparative Project) dataset (De Sio et al. 2019). The project fielded pre-electoral CAWI surveys to samples designed to represent voting age population $(\mathrm{N} \approx 1000$ in each country) before general elections in Austria, France, Germany, Italy, Netherlands and UK between 2017 and 2018. These six elections came perhaps in the season that saw the most striking success of challenger parties, right after Brexit and the election of Donald Trump. ${ }^{5}$ A distinctiveness of these surveys lies in the large number of issues included (approx. 30 in each country) and in the country-specific issue operationalization: for each election, country experts identified issues expected to be relevant in the campaign, and developed corresponding items aimed at capturing the actual, country-specific issue framing at campaign time in both general (positional/valence) and specific (question wording) terms (D’Alimonte, De Sio, and Franklin 2020).

Goal credibility items as issue-specific voter-party affinities, generalizable across positional and valence issues

Perhaps the key distinctiveness of ICCP surveys lies in the adoption of homogeneous measurement of

\footnotetext{
${ }^{5}$ For details see D'Alimonte, De Sio and Franklin (2020) and the specific country analyses included in the ICCP special issue of West European Politics (De Sio and Lachat 2020a).
}

respondent issue attitudes across both positional and valence issues. This is achieved (see D'Alimonte, De Sio, and Franklin 2020 for details) by first introducing a reconceptualization of political issues in terms of the more general concept of political goal (Parsons, Bales, and Shils 1953), with positional and valence issues simply differentiated by the number and opposition of goals involved (two rival goals for positional issues, one shared goal for valence issues; see Stokes 1963). This reconceptualization also affects the related notion of respondent-party affinity on a given issue. Classic operationalization of such affinity differentiates between items capturing party competence on valence issues, and party and respondent positions on positional issues (allowing to compute respondent-party proximity as a measure of issue affinity). This leads to party affinity measures that clearly differ across the two types of issues in question wording and in their construction process. ICCP instead introduces the more general notion of party credibility to achieve a particular goal, arguing that, unlike the notion of "competence" (appropriate for technical, a-partisan shared goals, but not for divisive, controversial goals defining positional issues) the notion of "credibility" can more appropriately capture the attitudes that a respondent (R) has towards the ability of a certain party to achieve a certain goal, be it divisive or shared, and the issue-related motivations that might drive $\mathrm{R}$ to vote for that party (D'Alimonte, De Sio, and Franklin 2020; see also De Sio, Mannoni, and Paparo 2020).

In measurement terms, this allows to achieve almost full homogeneity across the two types of issues. The only difference is that, for positional issues, respondents are additionally first asked to select one of two rival goals. ${ }^{6}$ After this point, the same instrument is employed in both cases: a goal label (reporting either the default shared goal - for valence issues - or the R-selected rival goal - for positional issues), followed by a multiple-choice question, asking - for each party - which parties $\mathrm{R}$ considers credible to achieve the goal (D'Alimonte, De Sio, and Franklin 2020). This item generates a set of party-specific, respondent-assessed issue credibilities, capturing a general notion of issue-specific voter-party affinity across goals, applicable to both positional and valence issues.

\section{Party-specific vote change as dependent variable}

Coming to our analysis strategy, its first distinctive element lies in the dependent variable (individual

\footnotetext{
${ }^{6}$ They are asked to position themselves on an even-numbered (6-point) scale, which allows dichotomous identification of a preferred rival goal, but also offers flexibility for traditional proximity applications.
} 
vote change). Separately for each party, this is computed based on two dummy variables (past vote; vote intention) that code, respectively, whether $\mathrm{R}$ voted the party in the last general election and whether she intends to vote it in the coming general election. ${ }^{7}$ These two variables easily allow to compute whether $\mathrm{R}$ has actively joined the party $(+1)$ or has stayed neutral (0), i.e. whether $\mathrm{R}$ has contributed an inflow to the party. It is important to stress that this vote change (rather than vote choice) is the genuine micro-level phenomenon producing the aggregate electoral change (increases and decreases for each party) that decides an election. In other words, we argue that studying vote change (rather than vote choice) provides a direct insight into the factors that decide an election result. ${ }^{8}$

\footnotetext{
${ }^{7}$ Ideally, the most appropriate choice would imply: (a) using (relatively reliable) last vote, election-specific vote recalls in a long-term panel dataset; or (b) when dealing with a single-election pre-post panel dataset (as in the ICCP case) a comparison between past vote and post-electoral vote recall rather than pre-electoral vote intention. However, the ICCP dataset - while offering a two-wave, pre-post panel design, with the post-election survey including vote recall - features a lower number of respondents in the second wave of the panel. While acceptable for most applications, this limitation appears particularly problematic when modeling vote change as a function of approx. 30 issues (plus controls), as in fact the effects of this large number of issues would be estimated on a relatively low number of respondents who changed their party in between the two elections. At the same time, we argue that individual vote change is still largely captured already at pre-electoral time (few weeks before the election, when most ICCP surveys were fielded), as it is also the result (aside to short-term factors such as the electoral campaign) of longer-term factors related to the whole experience of the legislature and whose effects are already crystallized in the last weeks before the vote. As a consequence, vote intention should be able to already capture a significant part of the actual electoral change about to come (as indeed confirmed by the large number of effects we detected). As a consequence, we decided to employ vote intentions from the pre-electoral wave, rather than vote recall from the post-electoral, to maximize the number of respondents and estimate more robust effects; and we deem that these advantages clearly outweigh the disadvantages.

${ }^{8}$ In practice, our approach implies relaxing the assumption (implicit in standard models of vote choice) that factors attracting new voters are the same preserving the existing constituency. Indeed, our model of vote change ( 1 for joining the party, 0 for not joining the party, excluding stable party voters and party quitters) can be considered a binary model of being part of set JP (joining the party) vs. being part of sets JO (joining other parties) or NJ (not joining any). A separate model of party loyalty would instead model being part of S (stable party voters) vs. QP (quitting the party). The two models cover fully separate subsets of the sample, and they jointly cover the whole sample. At the same time, pooling cases from the two models together in a single model would yield a third model of $\mathrm{JP}+\mathrm{S}$ vs. $\mathrm{JO}+\mathrm{NJ}+\mathrm{QP}$; but this is in fact a model of voting the party vs. not voting it: a standard model of vote choice. This effectively shows that, indeed, estimating a standard model of vote choice is equivalent to the assumption that the determinants of party loyalty are the same determinants of joining a party. But this assumption is clearly untenable: not only (for obvious reasons) for predictors such as party identification, but also for issue-related predictors. Indeed, the literature (see De Sio and Weber 2014) already distinguishes between pamper issues (aimed at pampering and cultivating the existing
}

\section{Predictors and modelling choice}

As control variables, we adopt rural/urban residence (4 levels), sex, age class (5 classes), education (3 levels), political interest (1-4 scale), self-assessed living standards (1-7), and intensity of party closeness (from $0=$ no party closeness to $3=$ very close). Coming to our focal predictors of vote change, they are represented by the aforementioned, party-specific dichotomous goal credibility predictors (whether R considers a party credible to achieve an issue goal). In general, we expect attraction of a voter towards a party (vote change $=1$ ) to be associated with a perception of party credibility on key issues. In addition, it is important to note that, for positional issues, these credibility dummies are unsigned, i.e. they do not include which of the two rival goals (e.g. pro- vs. anti-EU) was selected by the respondent, and thus used as reference for assessing party credibility. This is by design, and it allows to: (a) avoid theoretical assumptions about the perceived issue orientation of a particular party, leaving this to empirical determination (even parties without official issue positions are often clearly perceived on one of two rival sides); (b) estimate a model that includes all issues (and all inflows for that party) without the complexity of separately managing rival issue orientation predictors across multiple issues; (c) avoid collinearity issues that might inappropriately assign "wrong" signs to some significant effects. ${ }^{9}$ As a result, our models simply identify, in the first place, which issue credibilities significantly predict inflow towards a party. Then, to determine which of the two rival issue sides drove such inflow, we perform a simple post-hoc analysis: we build a signed version of the issue credibility variable (e.g. -1 for deeming the party credible on the anti-EU side; 0 for not deeming the party credible on the chosen EU goal; +1 for deeming the party credible on the pro-EU side) and simply run a

party base) and bridge issues (aimed at building bridges towards new voters); moreover, we performed separate estimations of S vs. QP models (available upon request) which clearly show how issue predictors of party loyalty are different from predictors of joining the party. This reinforces even more, we argue, the relevance of our innovative focus on vote change.

${ }^{9}$ Such collinearity issues occasionally happen when including a large number of signed issue predictors in a model: issue predictors that have a theoretically meaningful (and significant) effect in a single-issue model (with controls) occasionally end up with a significant, reversed sign in a model with many issue predictors, especially when other predictors from the same issue domain are included in the model. Using the unsigned version prevents this problem, by simply identifying issue relevance without sign (i.e. no political direction). Also, for these unsigned versions a directional hypothesis applies (a positive effect is expected: issue credibility associated with joining the party) so that we always consider negative coefficients non-significant, as they fail a one-tailed positively-signed significance test. 
single-issue model (with controls) of joining the party: the sign of this single issue effect allows to characterize the issue effect with an ideological sign (progressive/ conservative orientation) ${ }^{10}$; in the few cases where this single-issue effect is not significant (usually for small or losing parties, i.e. with a low number of joiners, or when party joiners are evenly split across rival goals) we leave the characterization unsigned. ${ }^{11}$ The final result of our analysis is then the identification of the issue goals that drove vote inflows for each party; ${ }^{12}$ and the final combined reading of relevant issues for all parties provides an effective issue characterization of the elections under analysis.

\section{FINDINGS}

We summarize results for all our binary logistic regression ${ }^{13}$ models (one for each party ${ }^{14}$ ) in Table 1. Each row, showing results for one party model, reports logit coefficients for statistically significant issue credibility predictors of joining each party, with significance levels. Each coefficient is also prepended by a letter denoting the goal orientation ( $\mathrm{P}$ for the "progressive" side, C for the "conservative" side) that significantly predicts joining that party (see above); thus, for example, the "P" labelling the significant coefficient for "Economic policy" for GroenLinks in the Netherlands, means that: deeming GroenLinks credible on the progressive side on an issue regarding economic policy ${ }^{15}$ had a significant

\footnotetext{
${ }^{10}$ For each issue, we assigned the two rival goals to a progressive or conservative side based on the ideal typical conceptualization of $20^{\text {th }}$ century ideological views introduced by Middendorp (1978). See De Sio and Lachat (2020b) for details.

${ }^{11}$ To avoid significant loss of cases, we recoded missing credibilities to no credibility for a party. Also, "stable" voters (voting for the party both in the past and intending to vote it in the coming election) were excluded from the analysis, as they would alter the characteristics of the "zero vote change" rows that act as comparison for nonzero rows in the estimation of the likelihood function.

${ }^{12}$ In principle, one could estimate models of both inflows (joining the party) and outflows (leaving the party), thus identifying issue drivers of both components. However, while issue determinants of outflows might be of interest for assessing individual party strategies, this is not the focus of this paper; we only analyse determinants of inflows in order to characterize the election through issue determinants of electoral success. ${ }^{13}$ Alternatively to our party-specific binary logistic models, one could estimate one multinomial logistic regression model per country, where the dependent variable codes joining one of multiple parties vs. not joining any. However, as our main predictors (issue credibilities) are party-specific, they cannot be used in a multinomial logistic model: a party-specific setup is required.

${ }^{14}$ We excluded from estimation all parties and candidates below $3 \%$ in the last general election, to avoid potential numeric instability issues due to a very low number of party joiners.

${ }^{15}$ In this case, the issue of income differences, defined by the two rival statements "Reduce income differences" vs. "Don't reduce income dif-
}

effect on joining the party. C is instead reported where credibility on the conservative side of an issue predicts joining a party, while a $\mathrm{V}$ is reported for valence issues, where credibility on the single "shared" goal is a significant predictor of joining a party. ${ }^{16}$

Given the amount of information reported (the table summarizes significant effects for 38 models of vote change, one for each party, with effects grouped by 10 policy domains), a first overall issue characterization of the whole election season (across six countries) is facilitated by summary rows at the bottom. These report counts of parties presenting significant issue effects in a particular policy domain (first summary row), followed by the balance of conservative vs. progressive goal effects (along with a count of valence goal effects). These summaries are then calculated separately for challenger parties, to provide more detail on these latter.

This first piece of information already provides key evidence for assessing (indeed disconfirming) the first proposition we derived from the literature, i.e. a clear predominance of non-economic, broadly "cultural" issues. This clearly does not appear supported by the data: if we look at the total number of parties rewarded by different issue domains, we clearly see that dominant issue domains (by party impact) are clearly economic. Issue goals related to welfare significantly rewarded 21 of the 38 parties, while economic policy rewarded 19 parties. The first non-economic issue domain (the EU) ranks third (13 parties affected), followed however by immigration, institutional reforms, and another economic domain (the job market) with 9 parties significantly affected. All other cultural issue domains impacted electoral inflows for less than 9 parties (the environment for 7 parties, individual liberties and law and order for 5 parties). All in all, what appears is a clear prevalence of economic over non-economic, broadly "cultural" issues. And this prevalence is also essentially confirmed when looking at the subset of the largest winners (i.e. the top 10 parties/candidates by performance): among these, welfare issues rank first, with 6 top 10 parties affected; followed by the EU (5 parties affected) and the job market and the environment (4 parties affected).

Of course, after the identification of relevant issue domains, actual issue characterization of these elections

ferences". See the Appendix for actual country-specific issue statements with significant effects for each party.

${ }^{16}$ No orientation is reported when - while issue relevance is significantly detected - the signed version of the issue predictor does not yield a significantly-signed goal orientation (see the previous section). In substantive terms, this can be due to: (a) low number of party joiners; (b) a potential issue stance ambiguity, when different voters deem the party credible, but projecting (their own) rival positions on an ambiguous party. We do not explore this further in the paper. 
requires assessing the prevailing (if any) policy direction (conservative/progressive) of these effects. Indeed, assessment of this balance of effects across policy domains provides interesting insights, especially showing differences across economic and cultural issues. First and foremost, economic issues clearly show an overwhelming dominance of progressive issue goals. This is clearly the case for economic policy (11 progressive vs. 0 conservative effects) and welfare (7 vs. 0). Some of these effects are best understood with more detail about the actual issue statements in each country (see the Appendix for a full list): in general, significant effects in the economic policy domain are all from statements on income redistribution (thus observed orientations are pro income redistribution), while those in the welfare domain (both for valence and positional formulations) typically concern aspects such as preserving pension age, public healthcare systems, and schooling. Regarding the job market, although the progressive vs conservative balance is 1 to 1 , we also observe that most of the significant effects on vote inflows derive from valence goals: these are mostly concerned with the reduction of unemployment, thus with positions clearly, again, asking for more protection in the economic arena.

Interestingly enough, credibility on the dominant progressive stance across economic domains rewarded not only left-wing parties, but also parties such as Geert Wilders' PVV in the Netherlands (supporting reduction of income differences) and even Marine Le Pen in France (supporting reduction of income differences and preservation of pension age against possible increases): these parties, to some extent unsurprisingly, clearly appear to capture a demand for protection in the economic arena. We deem this point important. On the one hand, this presence of same-sign effects across parties of different families confirms the emergence of post-ideological strategies combining credibility on both classically (in traditional $20^{\text {th }}$ century ideologies) progressive and conservative policy goals (De Sio and Lachat 2020b); on the other hand, this unexpectedly simplifies the overall interpretation of citizens preferences across multiple countries. While success and defeat hit different party families in different countries (depending on party platforms influenced by country-specific patterns of party competition), issue drivers of vote inflows appear instead more similar, thus - paradoxically - providing an issue characterization that is even more parsimonious than a party-based characterization (more on this point later).

This clear dominance of one policy side is, however, not mirrored on non-economic issues, which appear more controversial and polarized. First and foremost, the EU integration domain shows a $8 / 6$ balance, with vote inflows driven in 8 cases by conservative (anti-EU) positions and in 6 by progressive positions. This antiEU prevalence becomes much stronger when looking at challenger parties only, turning into a 6/1 balance, confirming that the conflict over EU integration is strongly related to the mainstream/challenger distinction. Indeed, this clearly reminds of the original intuition by Lipset and Rokkan (1967), where political conflict emerged out of opposition to the policy orientations (on various issues) of the nation-building political elites. Also, this polarized pattern only partly applies to other noneconomic domains. Indeed, in the immigration domain we observe a prevalence of conservative effects (9 vs. 1 ), while for the remaining policy domains, progressive stances prevail, although with different degrees. For individual liberties we find 2 progressive issues against 1 conservative; for the environment the balance is 2 progressive issues against 0 conservative; while the institutional reform domain sees a balance of 3 progressive positions against 1 conservative. Finally, we find only valence statements for what concerns security, and "law and order" (4). Overall, such evidence about cultural, non-economic issues allows an (again, negative) assessment of our second proposition: indeed, the fact that dominant cultural issue stances clearly have different signs across different issue domains, combined with the frequently separate relevance of different cultural issue domains for different parties, suggests that these issues - in empirical terms -hardly combine in an overarching dimension dominating party competition.

While detailed effects and country-specific issue goal statements are reported in the Appendix, this general birds-eye view at significant effects (across issue dimensions) fueling vote inflows for 38 parties suggests that the overall issue characterization of the 2017-18 electoral season in these six Western European countries appears quite different from what expected based on the literature. Despite expectations of a clear dominance of cultural issues (and perhaps of conflicts related to a "transnational cleavage"), party inflows - when properly analyzed at the individual level - appear instead mostly driven by economic issues. And these express identifiable policy demands, with parties rewarded by being perceived credible on traditionally progressive goals related to income redistribution, preservation of regulations in the job market (and fight to unemployment), and reinforcement of welfare services. On the contrary, cultural issues show a more controversial picture on both EU integration and immigration (with conservative stances dominantly rewarded on immigration), while environmental issues show more homogeneous prevalence of pro-environmental stances. In a way, this latter hetero- 
Table 1. Summary of significant issue effects on vote inflows for parties and candidates (above 3\%), listed by electoral performance (binary logistic model estimates, with controls listed in main text; one model per row; see Appendix for full models and N).

\begin{tabular}{|c|c|c|c|c|c|c|c|c|c|c|}
\hline \multirow{2}{*}{$\begin{array}{l}\text { Party/candidate } \\
\text { ("challengers" in } \\
\text { italics) }\end{array}$} & \multirow{2}{*}{$\begin{array}{l}\text { Electoral } \\
\text { perf. vs } \\
\text { previous } \\
\text { election }\end{array}$} & \multicolumn{3}{|c|}{$\begin{array}{c}\text { Significant issue effects: } \\
\text { economic policy domains } \\
\text { (with Prog/Cons/Valence } \\
\text { orientation) }\end{array}$} & \multicolumn{6}{|c|}{$\begin{array}{l}\text { Significant issue effects: } \\
\text { "Cultural" policy domains }\end{array}$} \\
\hline & & $\begin{array}{c}\text { Economic } \\
\text { policy }\end{array}$ & Job market & Welfare & $\begin{array}{l}\text { Immigra- } \\
\text { tion }\end{array}$ & $\begin{array}{l}\text { Individual } \\
\text { liberties }\end{array}$ & $\begin{array}{l}\text { Secu- } \\
\text { rity, law and } \\
\text { order }\end{array}$ & $\begin{array}{l}\text { Environ- } \\
\text { ment }\end{array}$ & EU & Institutions \\
\hline PILZ (at) & $\infty$ (new) & & & V $1.403^{\star *}$ & & & & & & \\
\hline Macron (fr) & $\infty$ (new) & & $\begin{array}{c}\text { C } 1.719^{* * *} \\
\text { V } .722^{*}\end{array}$ & V $.935^{\star *}$ & & & & & P $.977^{\star *}$ & \\
\hline Più Europa (it) & $\infty$ (new) & & & V $1.829^{*}$ & & & & V $2.496^{* *}$ & & \\
\hline Lega (it) & $+324 \%$ & & & & C $1.603^{*}$ & & V $1.235^{*}$ & & C $1.251^{\star}$ & \\
\hline GroenLinks (nl) & $+296 \%$ & P $1.272^{* * *}$ & & P $0.744^{*}$ & & & $0.868^{*}$ & V $0.999^{* *}$ & P $1.018^{\star *}$ & \\
\hline$A F D(d e)$ & $+168 \%$ & & & & $\begin{array}{l}\text { C } 1.662^{* *} \\
\text { C } .932^{*}\end{array}$ & & & & & \\
\hline Dupont-Aignan (fr) & $+161 \%$ & & & & & & & & $\begin{array}{l}5.266^{* * *} \\
\text { V } 3.808^{*}\end{array}$ & \\
\hline FDP (de) & $+123 \%$ & & V $1.162^{*}$ & & C $1.463^{* *}$ & & & V .989* & & \\
\hline FdI (it) & $+120 \%$ & & V $5.207^{\star \star \star}$ & V $3.529^{* *}$ & & & & & & \\
\hline Mélénchon (fr) & $+76 \%$ & & $2.544^{* * *}$ & V $1.229^{* *}$ & & & & P $1.084^{* *}$ & P $1.248^{* *}$ & V $1.484^{* * *}$ \\
\hline PvdD (nl) & $+68 \%$ & P $2.286^{\star * *}$ & & & & P $1.112^{*}$ & & & & $1.527^{\star}$ \\
\hline 50plus (nl) & $+63 \%$ & P $1.907^{* * *}$ & & $\begin{array}{l}\text { V } .820^{*} \\
\text { P } 1.161^{* *}\end{array}$ & & & & & & \\
\hline D66 (nl) & $+53 \%$ & $\begin{array}{c}\text { V . } 726^{*} \\
\text { P } 2.054^{* * *}\end{array}$ & & & & & & & & \\
\hline $\mathrm{CDA}(\mathrm{nl})$ & $+46 \%$ & $1.036^{*}$ & V $1.182^{* *}$ & & & & & & & \\
\hline ÖVP (at) & $+31 \%$ & & & V . $657^{\star}$ & C $1.034^{* * *}$ & & & & & P. $.604^{*}$ \\
\hline Lab (uk) & $+31 \%$ & & & P $1.113^{* *}$ & & & & & & V $1.074^{* *}$ \\
\hline$P V V(n l)$ & $+30 \%$ & P $1.470^{\star * *}$ & & & $\begin{array}{l}\text { C } .994^{* *} \\
\text { C } .955^{*}\end{array}$ & & & & C $.816^{*}$ & \\
\hline M5S (it) & $+29 \%$ & & & V $1.827^{* *}$ & & & & & & V $1.349^{*}$ \\
\hline FPÖ (at) & $+27 \%$ & & & V $1.045^{*}$ & & & & & C $1.592^{\star * *}$ & $\mathrm{P} 1.200^{* *}$ \\
\hline Le Pen (fr) & $+19 \%$ & P $1.071^{*}$ & $\begin{array}{c}1.412^{* *} \\
\text { V } 1.090^{*}\end{array}$ & P $1.085^{*}$ & & V $1.145^{* *}$ & & & $\begin{array}{c}\text { V } .773^{*} \\
\text { C } 1.323^{* * *}\end{array}$ & \\
\hline Cons (uk) & $+15 \%$ & & & & & & & & $\begin{array}{c}\text { C } .900^{*} \\
\text { C } 1.203^{* *}\end{array}$ & V $1.279^{* * *}$ \\
\hline $\mathrm{CU}(\mathrm{nl})$ & $+10 \%$ & & & & & C $2.614^{* *}$ & & & & \\
\hline NEOS (at) & $+6 \%$ & P $1.445^{\star}$ & & & & & & $1.751^{\star}$ & & \\
\hline B90/Grünen (de) & $+6 \%$ & $2.738^{* *}$ & & P $2.371^{*}$ & & & & & & P $1.581^{*}$ \\
\hline LeU (it) & $+3 \%$ & & & P $2.174^{*}$ & & & V $2.554^{\star}$ & & & \\
\hline SPÖ (at) & $+0 \%$ & $1.240^{* *}$ & & V $1.248^{*}$ & $1.168^{\star *}$ & & & & P $1.056^{*}$ & \\
\hline$S P(n l)$ & $-6 \%$ & P $2.043^{* * *}$ & & & & & V $.883^{*}$ & & & \\
\hline LibDem (uk) & $-6 \%$ & P $1.242^{*}$ & & V $1.970^{* *}$ & & & & & P $1.577^{\star}$ & C $1.279^{*}$ \\
\hline SPD (de) & $-20 \%$ & P $1.301^{\star *}$ & & V $1.087^{\star}$ & & & & & & \\
\hline CDU-CSU (de) & $-20 \%$ & & & & $\begin{array}{l}\text { P. } .914^{*} \\
\text { C. } .997^{*}\end{array}$ & & & P $.986^{* *}$ & & \\
\hline VVD (nl) & $-20 \%$ & $2.156^{\star * *}$ & & V $1.411^{\star}$ & & & & & & \\
\hline Fillon (fr) & $-26 \%$ & $3.043^{*}$ & $4.327^{\star *}$ & & C $3.718^{*}$ & V $3.557^{\star}$ & & & & \\
\hline PD (it) & $-29 \%$ & V $3.562^{*}$ & V $3.819^{*}$ & & & & & & P $4.413^{*}$ & \\
\hline FI (it) & $-36 \%$ & & & $\begin{array}{l}\text { P } 1.712^{*} \\
\text { V } 2.002^{*}\end{array}$ & & & V $2.687^{* *}$ & & & \\
\hline
\end{tabular}


Table 1. (Continued).

\begin{tabular}{|c|c|c|c|c|c|c|c|c|c|c|}
\hline \multirow{2}{*}{$\begin{array}{l}\text { Party/candidate } \\
\text { ("challengers" in } \\
\text { italics) }\end{array}$} & \multirow{2}{*}{$\begin{array}{l}\text { Electoral } \\
\text { perf. vs } \\
\text { previous } \\
\text { election }\end{array}$} & \multicolumn{3}{|c|}{$\begin{array}{l}\text { Significant issue effects: } \\
\text { economic policy domains } \\
\text { (with Prog/Cons/Valence } \\
\text { orientation) }\end{array}$} & \multicolumn{6}{|c|}{$\begin{array}{l}\text { Significant issue effects: } \\
\text { "Cultural" policy domains }\end{array}$} \\
\hline & & $\begin{array}{l}\text { Economic } \\
\text { policy }\end{array}$ & Job market & Welfare & $\begin{array}{l}\text { Immigra- } \\
\text { tion }\end{array}$ & $\begin{array}{l}\text { Individual } \\
\text { liberties }\end{array}$ & $\begin{array}{l}\text { Secu- } \\
\text { rity, law and } \\
\text { order }\end{array}$ & $\begin{array}{l}\text { Environ- } \\
\text { ment }\end{array}$ & $\mathrm{EU}$ & Institutions \\
\hline Grüne (at) & $-69 \%$ & $2.465^{\star *}$ & & V $1.789^{*}$ & & & & & $2.729^{*}$ & \\
\hline $\operatorname{PvdA}(\mathrm{nl})$ & $-77 \%$ & V $2.310^{* *}$ & P $1.815^{*}$ & & & $\begin{array}{l}2.234^{* *} \\
1.798^{*}\end{array}$ & & & & \\
\hline Hamon (fr) & $-78 \%$ & $\begin{array}{l}\text { V } 1.729^{*} \\
\text { P } 1.902^{\star}\end{array}$ & & & & & P $1.543^{*}$ & & & \\
\hline UKIP (uk) & $-86 \%$ & & & V $1.926^{*}$ & & & & & & $\begin{array}{l}\text { C } 1.484^{*} \\
\text { C } 1.259^{*}\end{array}$ \\
\hline $\begin{array}{l}\text { Total parties } \\
\text { affected (of } 38 \\
\text { parties) }\end{array}$ & & 19 & 9 & 21 & 9 & 5 & 5 & 7 & 13 & 9 \\
\hline $\begin{array}{l}\text { Cons/prog effect } \\
\text { balance (and } \\
\text { valence effects) }\end{array}$ & & $0 / 11(4)$ & $1 / 1(6)$ & 0/7 (16) & $9 / 1(0)$ & $1 / 2(2)$ & $0 / 0(4)$ & $0 / 2(3)$ & $8 / 6(2)$ & $1 / 3(4)$ \\
\hline $\begin{array}{l}\text { Challengers } \\
\text { affected (of } 11 \\
\text { challengers) }\end{array}$ & & 3 & 3 & 6 & 3 & 1 & 2 & 1 & 7 & 3 \\
\hline $\begin{array}{l}\text {...and cons/prog } \\
\text { balance }\end{array}$ & & $0 / 3(0)$ & $0 / 0(2)$ & 0/1 (5) & $5 / 0(0)$ & $0 / 0(1)$ & $0 / 0(2)$ & $0 / 1(0)$ & $6 / 1(2)$ & $0 / 1(2)$ \\
\hline
\end{tabular}

Note: ${ }^{\star} \mathrm{p}<0.05 ;{ }^{* *} \mathrm{p}<0.01 ;{ }^{* *} \mathrm{p}<0.001$.

geneity across cultural issues gives us, indirectly, a further relevant finding: there appears no evidence of a clearly polarized common "cultural" dimension on noneconomic issues, as electorally rewarding stances are mixed across conservative and progressive positions in these different, "cultural" issue domains.

This finally resonates with an observation about the ideological consistency of different parties. Evidence from Table 1 clearly shows the relevance of "cross-ideological" mobilization, i.e. the ability of some parties to attract voters across the board, leveraging credibility on different issues - on a combination of traditionally progressive and traditionally conservative stances. This argument appears clearly visible in examples such as Marine Le Pen and Emmanuel Macron: the former is rewarded both by conservative stances on the EU and progressive stances on economic policy and welfare; while the latter's success appears driven by - mirrored - progressive stances about the EU, but conservative stances on the job market; both appear exemplifications of two ideal types of cross-ideological mobilization previously labeled "welfare nationalists" and "free-market cosmopolitans" (see in detail De Sio and Lachat 2020b).
This point is relevant for the scope of this article, revealing the inadequacy of a simple party-based characterization of electoral change that ignores the actual issue determinants of vote change. Without issue-based, individual-level findings, it is impossible to understand cross-ideological appeals such as the case of Marine Le Pen (usually simply portrayed as a radical right-winger). Furthermore, compared to classic party-based characterization, relying on party families or party types, our issue-based approach surprisingly proves more parsimonious. As party platforms reflect country-specific party competition patterns, this inevitably leads to country differences making hard to characterize election results across multiple countries. To some extent surprisingly, our party-family-agnostic unpacking of individual-level issue determinants of party success reveals that indeed there are common policy orientations that rewarded parties across the board in multiple countries, making paradoxically easier to determine the pattern of citizen preferences that fueled electoral change in six Western European countries between 2017 and 2018. Indeed, these patterns reveal a common demand for economic protection and for limiting 
immigration, albeit combined with progressive stances on environmental protection, and with EU issues more plural and controversial, rewarding parties on both rival sides of this conflict.

\section{CONCLUSIONS}

In this paper we identified the issue of the substantive issue characterization of electoral change, i.e. the aim (of great importance for democratic representation) of identifying specific configurations of citizen preferences that drive a particular electoral change. Looking in perspective, we identified how, in most cases, this effort is pursued based on only indirect information (e.g. the party platform of a winning party, without knowing what actual issue stance drove the success of the party), with a potential for significant biases emerging in the process. Relying on the innovative, issue-oriented ICCP dataset (featuring rich measurement of issue attitudes across a large number of issues, captured in their country-specific framings), we proposed a novel methodology for modelling issue determinants of electoral change at the appropriate individual level, estimating models of individual vote change (towards a party) based on respondent-perceived party credibility on specific issue goals. This allowed us (pooling together different country-specific issue statements into common issue domains) to estimate issue determinants of vote inflows across all relevant parties in six Western European countries in 2017 and 2018 (both winning and losing parties, as these latter also attract vote inflows). Results indeed showed the relevance of this methodology, by clearly contradicting many current interpretations of recent electoral change in Western Europe, which - based on the visibility of cultural issues in many "challenger" parties - claimed a dominant relevance of these non-economic issues. In fact the opposite appears to be true: when properly analysing electoral change at the individual level, a clear dominance of the effects of economic issues emerges (in terms of parties affected), with a large prevalence of rewards for credibility on progressive stances, clearly voicing a demand for economic protection. Non-economic, "cultural" issues matter, but affecting a smaller number of parties; rewarding conservative stances on immigration, but progressive stances on the environment (thus disconfirming the expectation of a common, polarized cultural dimension), and finally with more polarization on the EU dimension. Perhaps this polarization (rewarding both pro- and anti-EU stances) explains the visibility of the EU issue in political comments and the literature; but this visibil- ity - and this, we argue, is an important contribution of this paper - should not be misunderstood for an actual relevance of the issue in driving electoral change. The fact that parties adopt different stances (thus with a publicly visible debate) does not necessarily mean that this issue is a dominant dimension for vote choice; in comparison, economic issues clearly dominated vote inflows, thus appearing definitely more relevant for electoral change across different Western European countries.

This distinctiveness of our findings demonstrates, in our view, a first important result in terms of the broader methodological aims of this paper, along with its implications for future research: individual level, issue-based characterization of electoral change matters. It does so as it removes a number of biases in the actual reconstruction of the configurations of citizen preferences that determined electoral outcomes. But there is a second aspect to which we argue this methodology contributes: the possibility of parsimonious characterization of electoral change across multiple countries. Somehow surprisingly, we found that - beyond the idiosyncrasies of specific party systems - similar issue determinants fuelled the success of parties from different party families in different countries. While, on the one hand, this demonstrates how many parties by now adopt cross-ideological strategies, on the other hand this demonstrates how, beyond the party labels they reward, the demands of citizens in different European countries might have more in common than usually thought. We deem this a promising finding, paving the way for parsimonious and effective identification of citizen demands, and - hopefully - for appropriate, effective policy responsiveness.

\section{REFERENCES}

Abou-Chadi, Tarik. 2016. "Niche Party Success and Mainstream Party Policy Shifts - How Green and Radical Right Parties Differ in Their Impact." British Journal of Political Science 46(2): 417-36.

Abou-Chadi, Tarik, and Werner Krause. 2020. "The Causal Effect of Radical Right Success on Mainstream Parties' Policy Positions: A Regression Discontinuity Approach." British Journal of Political Science 50(3): 829-47.

Angelucci, Davide, Lorenzo De Sio, and Aldo Paparo. 2020. "Europe Matters ... upon Closer Investigation: A Novel Approach for Analysing Individual-Level Determinants of Vote Choice across First- and Second-Order Elections, Applied to 2019 Italy." Italian Political Science Review / Rivista Italiana di Scienza Politica 50(3): 334-49. 
Angelucci, Davide, and Pierangelo Isernia. 2020. "Politicization and Security Policy: Parties, Voters and the European Common Security and Defense Policy." European Union Politics 21(1): 64-86.

Arrow, Kenneth Joseph. 1951. Social Choice and Individual Values. New York: Wiley.

Barbagli, Marzio, Pier Giorgio Corbetta, Arturo Parisi, and H. M.A Schadee. 1979. Fluidità Elettorale e Classi Sociali in Italia. Bologna: Il Mulino.

Bélanger, Éric, and Richard Nadeau. 2005. "Political Trust and the Vote in Multiparty Elections: The Canadian Case." European Journal of Political Research 44(1): 121-46.

Black, Duncan. 1948. "On the Rationale of Group Decision-Making." The Journal of Political Economy 56(1): 23-34.

Bornschier, Simon. 2010. Cleavage Politics and the Populist Right: The New Cultural Conflict in Western Europe. Temple University Press.

Carrieri, Luca. 2020. The Impact of European Integration on West European Politics: Committed Pro-Europeans Strike Back. Palgrave.

Condorcet, Jean-Antoine-Nicolas de Caritat (1743-1794 ; marquis de). 1785. Essai Sur l'application de l'analyse à La Probabilité Des Décisions Rendues à La Pluralité Des Voix. Paris: Imprimerie Royale.

Corbetta, Pier Giorgio, and Hans M. A Schadee. 1984. Metodi e Modelli Di Analisi Dei Dati Elettorali. Bologna: Il Mulino.

Corbetta, Piergiorgio, Arturo Parisi, and H. Schadee. 1988. Elezioni in Italia: Struttura e Tipologia Delle Consultazioni Politiche. Bologna: Il Mulino.

Dahl, Robert Alan. 1971. Polyarchy: Participation and Opposition. New Haven; London: Yale University Press.

D'Alimonte, Roberto, Lorenzo De Sio, and Mark N. Franklin. 2020. "From Issues to Goals: A Novel Conceptualization, Measurement and Research Design for Comprehensive Analysis of Electoral Competition." West European Politics 43(3): 518-42.

Dalton, Russell J., and Steven A. Weldon. 2005. "Public Images of Political Parties: A Necessary Evil?” West European Politics 28(5): 931-51.

De Sio, Lorenzo. 2008. Elettori in Movimento. Nuove Tecniche Di Inferenza Ecologica per Lo Studio Dei Flussi Elettorali. Firenze: Polistampa.

De Sio, Lorenzo, Vincenzo Emanuele, Nicola Maggini, Aldo Paparo, Davide Angelucci, and Roberto D’Alimonte. 2019. "Issue Competition Comparative Project (ICCP) Dataset (Version 2.0.0) [ZA7499 Data File]." https://doi.org/10.4232/1.13374.

De Sio, Lorenzo, Mark N. Franklin, and Till Weber. 2016. "The Risks and Opportunities of Europe: How Issue
Yield Explains (Non-)Reactions to the Financial Crisis." Electoral Studies 44: 483-91.

De Sio, Lorenzo, and Romain Lachat. 2020a. "Issue Competition in Western Europe: An Introduction." West European Politics 43(3): 509-17.

- - . 2020b. "Making Sense of Party Strategy Innovation: Challenge to Ideology and Conflict-Mobilisation as Dimensions of Party Competition." West European Politics 43(3): 688-719.

De Sio, Lorenzo, Elisabetta Mannoni, and Aldo Paparo. 2020. "Anatomy of a Black Swan? Explaining the 2018 Italian Election Result through a Novel Issue Voting Model of Voter Transitions." COMUNICAZIONE POLITICA: 205-30.

de Vries, Catherine E. 2007. "Sleeping Giant: Fact or Fairytale? How European Integration Affects National Elections." European Union Politics 8(3): 363-85.

_-_. 2010. "EU Issue Voting: Asset or Liability? How European Integration Affects Parties' Electoral Fortunes." European Union Politics 11(1): 89-117.

de Vries, Catherine E., and Sara B. Hobolt. 2020. Political Entrepreneurs. The Rise of Challenger Parties. Princeton: Princeton University Press.

de Wilde, Pieter, Anna Leupold, and Henning Schmidtke. 2016. "Introduction: The Differentiated Politicisation of European Governance." West European Politics 39(1): 3-22.

de Wilde, Pieter et al., eds. 2019. The Struggle Over Borders: Cosmopolitanism and Communitarianism. Cambridge: Cambridge University Press.

Downs, Anthony. 1957. An Economic Theory of Democracy. New York: Harper.

Emanuele, Vincenzo, Bruno Marino, and Davide Angelucci. 2020. "The Congealing of a New Cleavage? The Evolution of the Demarcation Bloc in Europe (19792019)." Italian Political Science Review / Rivista Italiana di Scienza Politica 50(3): 314-33.

Franklin, Mark N., and Christopher Wlezien. 1997. "The Responsive Public: Issue Salience, Policy Change, and Preferences for European Unification." Journal of Theoretical Politics 9(3): 347-63.

Gelman, Andrew, and Gary King. 1993. "Why Are American Presidential Election Campaign Polls So Variable When Votes Are So Predictable?" British Journal of Political Science 23(4): 409-51.

Green-Pedersen, Christoffer, and Simon Otjes. 2019. "A Hot Topic? Immigration on the Agenda in Western Europe." Party Politics 25(3): 424-34.

Hale, Jon F. 1993. "Shaping the Conventional Wisdom." Political Communication 10(3): 285-302.

Han, Kyung Joon. 2015. "The Impact of Radical RightWing Parties on the Positions of Mainstream Parties 
Regarding Multiculturalism.” West European Politics 38(3): 557-76.

Hershey, Marjorie Randon. 1984. Running for Office: The Political Education of Campaigners. Chatam: Chatam House.

_-_. 1992. "The Constructed Explanation: Interpreting Election Results in the 1984 Presidential Race." The Journal of Politics 54(4): 943-76.

Hooghe, Liesbet, and Gary Marks. 2018. "Cleavage Theory Meets Europe's Crises: Lipset, Rokkan, and the Transnational Cleavage." Journal of European Public Policy 25(1): 109-35.

Hooghe, Liesbet, Gary Marks, and Carole J. Wilson. 2002. "Does Left/Right Structure Party Positions on European Integration?" Comparative Political Studies 35(8): 965-89.

Hooghe, Marc, and Ruth Dassonneville. 2018. "A Spiral of Distrust: A Panel Study on the Relation between Political Distrust and Protest Voting in Belgium.” Government and Opposition 53(1): 104-30.

Inglehart, Ronald. 1977. The Silent Revolution: Changing Values and Political Styles among Western Publics. Princeton: Princeton University Press.

Ivarsflaten, Elisabeth. 2008. "What Unites Right-Wing Populists in Western Europe? Re-Examining Grievance Mobilization Models in Seven Successful Cases.” Comparative Political Studies 41(1): 3-23.

King, Gary. 1997. A Solution to the Ecological Inference Problem: Reconstructing Individual Behavior from Aggregate Data. Princeton: Princeton University Press.

Kitschelt, Herbert. 1994. The Transformation of European Social Democracy. Cambridge University Press.

Kriesi, Hanspeter et al. 2006. "Globalization and the Transformation of the National Political Space: Six European Countries Compared." European Journal of Political Research 45(6): 921-56.

-__. 2008. West European Politics in the Age of Globalization. Cambridge: Cambridge University Press.

Kriesi, Hanspeter, and Julia Schulte-Cloos. 2020. "Support for Radical Parties in Western Europe: Structural Conflicts and Political Dynamics.” Electoral Studies 65: 102138.

Lewis-Beck, Michael Steven, and Richard Nadeau. 2011. "Economic Voting Theory: Testing New Dimensions." Electoral Studies 30(2): 288-94.

Lipset, Seymour M., and Stein Rokkan. 1967. "Cleavage Structures, Party Systems, and Voter Alignments: An Introduction." In Party Systems and Voter Alignments: Cross-National Perspectives., eds. Seymour M. Lipset and Stein Rokkan. New York: Free Press.

Mair, Peter. 2013. Ruling the Void: The Hollowing of Western Democracy. London; New York: Verso.

Mannheimer, Renato, ed. 1993. Quale Mobilità Elettorale?
Tendenze e Modelli. La Discussione Metodologica Sui Flussi Elettorali. Milano: Franco Angeli.

March, Luke. 2013. Radical Left Parties in Europe. Routledge.

Middendorp, Cees P. 1978. Progressiveness and Conservatism: The Fundamental Dimensions of Ideological Controversy and Their Relationship to Social Class. Walter de Gruyter.

Norris, Pippa, and Ronald Inglehart. 2019. Cultural Backlash: Trump, Brexit, and Authoritarian Populism. Cambridge: Cambridge University Press.

Parsons, Talcott, Robert F. Bales, and Edward Shils. 1953. Working Papers in the Theory of Action. New York: Free Press.

Pauwels, Teun. 2014. Populism in Western Europe, Populism in Western Europe. Abingdon: Routledge.

Pizzorno, Alessandro. 1993. Le Radici Della Politica Assoluta e Altri Saggi. Feltrinelli.

Rooduijn, Matthijs et al. 2019. “The PopuList: An Overview of Populist, Far Right, Far Left and Eurosceptic Parties in Europe." The PopuList. https://popu-list. org/ (February 13, 2021).

Rooduijn, Matthijs, and Brian Burgoon. 2018. "The Paradox of Well-Being: Do Unfavorable Socioeconomic and Sociocultural Contexts Deepen or Dampen Radical Left and Right Voting Among the Less WellOff?" Comparative Political Studies 51(13): 1720-53.

Rooduijn, Matthijs, Brian Burgoon, Erika J van Elsas, and Herman G van de Werfhorst. 2017. "Radical Distinction: Support for Radical Left and Radical Right Parties in Europe." European Union Politics 18(4): 536-59.

Schattschneider, Elmer E. 1942. Party Government. New York: Farrar and Rinehart.

Shamir, Michal, and Jacob Shamir. 2008. "What Were the Elections about, and Why We Should Ask about It in Election Surveys." International Journal of Public Opinion Research 20(2): 211-23.

Stokes, Donald E. 1963. "Spatial Models of Party Competition.” American Political Science Review 57: 368-77.

Thomassen, Jacques. 2005. The European Voter: A Comparative Study of Modern Democracies. Oxford: Oxford University Press.

Turnbull-Dugarte, Stuart J. 2020. “A New Hope for Europhiles? The 2017 German Federal Elections and the Revenge of the pro-European Mainstream." Journal of European Integration 0(0): 1-26.

Wagner, Markus, and Thomas M Meyer. 2017. “The Radical Right as Niche Parties? The Ideological Landscape of Party Systems in Western Europe, 1980-2014." Political Studies 65(1_suppl): 84-107.

Weber, Till. 2009. "When the Cat Is Away the Mice Will Play: Why Elections to the European Parliament Are 
about Europe after All." Politique europeenne 28(2): 53-71.

Werts, Han, Peer Scheepers, and Marcel Lubbers. 2013. "Euro-Scepticism and Radical Right-Wing Voting in Europe, 2002-2008: Social Cleavages, Socio-Political Attitudes and Contextual Characteristics Determining Voting for the Radical Right." European Union Politics 14(2): 183-205.

Zakaria, Fareed. 1997. "The Rise of Illiberal Democracy." Foreign Affairs 76(6): 22-43. 
APPENDIX - FULL MODELS’ SPECIFICATION IN EACH COUNTRY

\section{Austria}

Table A1. Binary logistic models of joining a party, based on issue goal credibilities, with controls (excludes stable party voters)

\begin{tabular}{|c|c|c|c|c|c|c|}
\hline & FPO & Grune & OVP & NEOS & Pilz & SPO \\
\hline Rural/Urban (1-4=Urban) & -0.233 & 0.694 & 0.0379 & -0.0779 & -0.0272 & -0.0611 \\
\hline Sex $(1=$ Woman $)$ & -0.407 & 0.720 & -0.0772 & 0.279 & -0.259 & 0.555 \\
\hline Age class $(1-5=65+)$ & -0.153 & -0.378 & $-0.294^{* *}$ & $-0.734^{* *}$ & -0.155 & $-0.376^{*}$ \\
\hline Education (1-3=Tertiary) & -0.460 & -0.149 & -0.297 & -0.191 & 0.493 & -0.323 \\
\hline Political interest (1-4=Very interested) & $-0.529^{*}$ & -0.595 & $-0.320^{*}$ & 0.332 & $0.659^{*}$ & 0.357 \\
\hline Living standards (1-7=Rich family) & 0.0800 & 0.459 & 0.100 & -0.0536 & -0.0218 & -0.181 \\
\hline Party closeness (0-3=Very close) & $2.024^{* * *}$ & 1.838 & $1.082^{* * *}$ & $2.217^{*}$ & $-a$ & 0.460 \\
\hline V! Providing affordable homes & 1.026 & $1.789^{*}$ & 0.133 & 0.0320 & 0.367 & 0.107 \\
\hline V! Fighting poverty of Elderly People & 0.564 & -1.789 & 0.290 & -0.632 & 0.302 & 0.459 \\
\hline V! Protect Austria against terrorist attacks & 0.882 & -0.175 & -0.123 & 0.339 & -0.121 & -0.817 \\
\hline V! Fight unemployment & 0.193 & 0.775 & 0.399 & 0.678 & 0.330 & -0.208 \\
\hline V! Support economic growth & -0.405 & 0.795 & 0.185 & 0.0279 & 0.228 & 0.651 \\
\hline V! Protect the environment & 0.433 & $-2.727^{*}$ & -0.0149 & 0.863 & -0.0244 & 0.849 \\
\hline V! Fight crime and keep our communities safe & -0.789 & 0.0541 & 0.311 & -0.689 & 0.777 & -0.665 \\
\hline V! Providing Social Justice & $1.045^{*}$ & 1.920 & $0.657^{*}$ & -0.208 & $1.403^{* *}$ & $1.248^{*}$ \\
\hline V! Control immigration & -0.0321 & -0.00409 & 0.127 & 1.138 & -0.427 & 0.114 \\
\hline V! Fight corruption & 0.209 & -0.189 & -0.0924 & 0.725 & 0.428 & -0.361 \\
\hline P! Keep current pension age or increase it & -0.173 & 0.466 & 0.262 & 0.312 & -0.905 & 0.612 \\
\hline P Reduce income differences or not & 0.297 & -2.149 & 0.0405 & $1.445^{*}$ & 0.908 & 0.295 \\
\hline P Taxes or social services & -0.177 & 0.173 & -0.0694 & 0.811 & -0.208 & -0.490 \\
\hline P Increase the minimum wage or not & $-1.200^{*}$ & -0.975 & 0.220 & -0.869 & -0.638 & 0.359 \\
\hline P Deregulate the job market or not & -1.066 & -0.244 & 0.376 & 1.131 & 0.640 & 0.715 \\
\hline P Abolish the obligatory membership in trade associations or not & 0.562 & 0.637 & -0.177 & 0.0858 & 0.485 & -0.772 \\
\hline P! Decrease unemployment at the expense of high national debt or not & -0.774 & 1.690 & 0.0113 & $-3.067^{* *}$ & 0.745 & 0.293 \\
\hline P Extend surveillance measures or not & 0.133 & -0.737 & 0.0822 & 0.768 & 0.491 & 0.659 \\
\hline P Austria should have a property tax on inheritance or not & 0.702 & $2.465^{* *}$ & 0.408 & 0.424 & 0.227 & $1.240^{* *}$ \\
\hline P Introduce stronger direct democracy measures or not & $1.200^{* *}$ & -0.196 & $0.604^{*}$ & 1.220 & 0.757 & 0.755 \\
\hline P Promoting sustainable energy or not & 0.318 & $2.729^{*}$ & -0.376 & $1.751^{*}$ & -0.806 & -1.022 \\
\hline P Diesel cars should be banned or not & -0.0649 & -0.558 & -0.295 & -0.388 & -0.230 & 0.356 \\
\hline P! Stay in the EU or leave it & $1.592^{* * *}$ & -1.291 & 0.343 & 0.798 & 0.173 & $1.056^{*}$ \\
\hline P! Keep current asylum rules or make them more restrictive & 1.536 & 0.131 & 0.471 & 0.330 & 0.375 & -0.0568 \\
\hline P! Restrict access to welfare benefits for immigrants or not & -0.219 & 0.825 & 0.290 & -0.488 & 0.453 & 0.783 \\
\hline P! Foreigners should fully adapt to Austrian culture or not & -0.268 & -0.553 & $1.034^{* * *}$ & 0.578 & 0.116 & $1.168^{* *}$ \\
\hline P! The EU has to enforce refugee quota or each country should decide by its own & 0.872 & 1.632 & -0.392 & -0.571 & $-1.344^{*}$ & 0.148 \\
\hline P End or allow freedom of movement from the EU & 0.0917 & 0.188 & -0.212 & -0.801 & -0.0789 & -0.0512 \\
\hline P Politics should implement gender quota or not & 0.109 & -0.387 & -0.156 & -0.291 & -0.289 & -0.122 \\
\hline P Allow gay marriages or not & 0.0368 & 1.822 & -0.438 & 0.0591 & 0.216 & 0.0815 \\
\hline P Introduce a comprehensive school for all children until 14 or not & -0.324 & -0.0211 & 0.122 & 0.304 & -0.868 & -0.523 \\
\hline Constant & $-2.533^{*}$ & $-7.867^{* *}$ & $-2.093^{* *}$ & $-4.958^{* *}$ & $-6.857^{* * *}$ & $-5.344^{* * *}$ \\
\hline Observations & 814 & 943 & 907 & 989 & 1037 & 855 \\
\hline Pseudo $R^{2}$ & 0.519 & 0.513 & 0.301 & 0.444 & 0.308 & 0.436 \\
\hline
\end{tabular}

$\mathrm{P}=$ positional issues, $\mathrm{V}=$ valence issues, ! denotes above-average aggregate issue saliency

${ }^{*} p<0.05,{ }^{* *} p<0.01,{ }^{* * *} p<0.001$

$-a$ Variables omitted for multicollinearity issues 


\section{France}

Table A2. Binary logistic models of joining a party, based on issue goal credibilities, with controls (excludes stable party voters)

\begin{tabular}{|c|c|c|c|c|c|c|}
\hline & Fillon & Hamon & Le Pen & Macron & Mélenchon & $\begin{array}{l}\text { Dupont- } \\
\text { Aignan }\end{array}$ \\
\hline Rural/Urban (1-4=Urban) & 0.249 & -0.161 & -0.0962 & -0.150 & 0.172 & 0.563 \\
\hline Sex (1=Woman $)$ & 1.504 & 0.282 & 0.141 & 0.261 & 0.337 & 1.197 \\
\hline Age class $(1-5=65+)$ & -0.487 & -0.128 & -0.0650 & -0.0928 & -0.0466 & 0.334 \\
\hline Education (1-3=Tertiary) & $2.203^{*}$ & -0.499 & 0.298 & -0.0466 & $-0.569^{*}$ & 0.295 \\
\hline Political interest (1-4=Very interested) & -0.991 & 0.0320 & $-0.579^{* *}$ & $-0.351^{*}$ & 0.0499 & $-1.467^{*}$ \\
\hline Living standards (1-7=Rich family) & 0.144 & -0.395 & -0.0562 & 0.199 & -0.114 & 0.459 \\
\hline Party closeness (0-3=Very close) & 0.688 & $1.575^{* * *}$ & $0.876^{*}$ & $-a$ & $0.870^{*}$ & $2.196^{*}$ \\
\hline V Make France count more in Europe & 1.244 & -0.779 & $0.773^{*}$ & 0.323 & 0.125 & $3.808^{*}$ \\
\hline V Make EU more democratic & -0.293 & 0.940 & 0.427 & -0.442 & $1.484^{* * *}$ & 0.360 \\
\hline V! Support economic growth & 0.983 & $1.729^{*}$ & 0.415 & 0.320 & 0.0942 & 0.385 \\
\hline V! Fight corruption & -1.452 & 0.928 & 0.434 & 0.507 & 0.173 & -0.563 \\
\hline $\mathrm{V}$ ! Protect the environment & -0.738 & -0.108 & -0.706 & $-0.991^{*}$ & -0.569 & $-a$ \\
\hline V! Protect France om the terrorist threat & -0.632 & -0.294 & 0.365 & 0.0758 & -0.707 & 1.249 \\
\hline V Make women's role in society more important & $3.557^{*}$ & $-2.024^{*}$ & $1.145^{* *}$ & -0.435 & -0.154 & 1.908 \\
\hline V! Fight unemployment & 1.139 & -0.0919 & $1.090^{*}$ & $0.722^{*}$ & 0.649 & $-7.361^{*}$ \\
\hline $\mathrm{V}$ ! Improve the quality of education & 1.828 & 1.594 & $-1.385^{*}$ & $0.935^{* *}$ & $1.229^{* *}$ & -3.234 \\
\hline P! Deregulate the job market or not & $4.327^{* *}$ & 1.153 & $1.412^{* *}$ & $1.719^{* * *}$ & $2.544^{* * *}$ & 1.882 \\
\hline P Lower or increase pension age & -1.754 & 0.853 & $1.085^{*}$ & 0.0815 & 0.0872 & 3.720 \\
\hline P! Reduce income differences or not & $3.043^{*}$ & -0.157 & $1.071^{*}$ & 0.524 & 0.565 & -4.899 \\
\hline P Limit or encourage economic globalisation & 0.949 & $1.902^{*}$ & -0.576 & -0.215 & $-1.053^{*}$ & -0.881 \\
\hline P! Stay in the EU or leave it & -2.778 & 0.693 & $1.323^{* * *}$ & $0.977^{* *}$ & -0.757 & $5.266^{* * *}$ \\
\hline P! Leave the Euro or not & 1.444 & -0.287 & -0.142 & 0.199 & $1.248^{* *}$ & -0.0864 \\
\hline P Abandon nuclear energy or not & -0.765 & -1.217 & -0.769 & -0.00459 & $1.084^{* *}$ & $-6.601^{*}$ \\
\hline P Restrict access to abortion or not & 1.158 & -0.371 & 0.783 & 0.371 & 0.224 & $-a$ \\
\hline P Legalise euthanasia or keep it illegal & 1.171 & -0.529 & $-1.562^{*}$ & 0.0752 & -0.177 & $-a$ \\
\hline P Repeal gay marriages or keep them & 0.252 & 0.675 & -0.361 & 0.0511 & 0.0622 & 3.508 \\
\hline P Legalise soft drugs or not & 1.269 & $1.543^{*}$ & -0.729 & 0.172 & 0.359 & 1.911 \\
\hline P! Keep current immigration rules or restrict them & 0.581 & 0.412 & 0.384 & 0.152 & -0.264 & 2.254 \\
\hline P! Restrict welfare for immigrants or not & $-7.283^{* *}$ & $-2.151^{*}$ & 0.345 & -0.315 & -0.116 & 0.567 \\
\hline P! Accept more refugees or limit them & $3.718^{*}$ & 0.344 & 0.258 & -0.328 & 0.107 & 0.539 \\
\hline P Forbid or authorise Islamic veil in public spaces & -2.740 & 0.627 & 0.400 & -0.0108 & -0.302 & -1.963 \\
\hline Constant & $-11.01^{* * *}$ & -2.710 & $-3.225^{* *}$ & $-2.896^{* * *}$ & $-3.724^{* * *}$ & $-8.634^{*}$ \\
\hline Observations & 923 & 878 & 901 & 1096 & 1040 & 1015 \\
\hline Pseudo $R^{2}$ & 0.616 & 0.447 & 0.457 & 0.376 & 0.474 & 0.612 \\
\hline
\end{tabular}

$\mathrm{P}=$ positional issues, $\mathrm{V}=$ valence issues, $!$ denotes above-average aggregate issue saliency

${ }^{*} p<0.05,{ }^{* *} p<0.01,{ }^{* * *} p<0.001$

$-a$ Variables omitted for multicollinearity issues 


\section{Germany}

Table A3. Binary logistic models of joining a party, based on issue goal credibilities, with controls (excludes stable party voters)

\begin{tabular}{|c|c|c|c|c|c|}
\hline & AfD & $\begin{array}{l}\text { B90/ } \\
\text { Grünen }\end{array}$ & $\mathrm{Cdu} / \mathrm{Csu}$ & FDP & SPD \\
\hline Rural/Urban (1-4=Urban) & 0.0760 & 0.0368 & 0.0985 & -0.157 & 0.0340 \\
\hline Sex $(1=$ Woman $)$ & -0.439 & $1.794^{*}$ & 0.317 & 0.588 & -0.596 \\
\hline Age class $(1-5=65+)$ & -0.105 & -0.328 & $-0.303^{*}$ & 0.113 & -0.114 \\
\hline Education (1-3=Tertiary) & -0.365 & $1.529^{* *}$ & 0.0804 & -0.00473 & -0.290 \\
\hline Political interest (1-4=Very interested) & $-0.535^{*}$ & -0.712 & -0.212 & -0.0874 & -0.201 \\
\hline Living standards (1-7=Rich family) & -0.0349 & 0.00718 & $-0.383^{* *}$ & $0.333^{*}$ & -0.105 \\
\hline Party closeness ( $0-3=$ Very close $)$ & $1.318^{*}$ & 0.809 & $0.591^{*}$ & $1.255^{* *}$ & $1.728^{* * *}$ \\
\hline V! Providing affordable homes & -0.248 & -0.511 & 0.700 & -0.498 & 0.439 \\
\hline V! Fighting poverty of elderly & 0.993 & 0.183 & -0.0183 & -0.217 & -0.000556 \\
\hline V Maintaining infrastructure & 1.396 & -0.178 & -0.657 & 0.435 & 0.0193 \\
\hline V! Protect from terrorism & 0.719 & -0.252 & -0.154 & -0.563 & 0.0690 \\
\hline V! Fight unemployment & 0.879 & -0.555 & 0.703 & $1.162^{*}$ & 0.281 \\
\hline V Support the economic growth & -1.144 & -0.136 & 0.276 & 0.159 & -0.490 \\
\hline $\mathrm{V}$ ! Protect the environment & -1.223 & -1.222 & 0.143 & $0.989^{*}$ & -0.180 \\
\hline V! Support for families and children & 0.212 & -1.689 & 0.469 & -0.375 & -0.309 \\
\hline V! Fighting crime & 0.0645 & 0.356 & -0.0545 & 0.355 & -0.591 \\
\hline V! Providing social justice & 1.017 & 1.281 & -0.105 & 0.207 & $1.087^{*}$ \\
\hline P! Limit the number of refugees or accept more of them & $1.662^{* *}$ & 0.416 & $0.997^{*}$ & 0.485 & 0.323 \\
\hline $\mathrm{P}$ ! Make immigration rules more restrictive or not & 0.906 & -0.886 & 0.0724 & $1.463^{* *}$ & 0.322 \\
\hline P! Keep the decision of nuclear power phase-out or withdraw from it & 0.899 & 2.192 & $0.986^{* *}$ & 0.883 & 0.481 \\
\hline P! The EU has to enforce refugee quota or each country should decide by its own & 0.217 & 1.008 & $0.914^{*}$ & -0.752 & -0.286 \\
\hline P! Stay in the EU or leave it & 0.596 & -0.464 & 0.0748 & 0.173 & 0.0669 \\
\hline P! Use the current budget surplus for reducing taxes or for infrastructure & 0.722 & $2.738^{* *}$ & 0.238 & 0.695 & $1.301^{* *}$ \\
\hline P! Increase pension age or keep it at current levels & -0.984 & -0.374 & 0.504 & $-1.163^{*}$ & 0.214 \\
\hline P Politics should implement gender quotas or not & 0.577 & $-2.107^{*}$ & 0.489 & -0.452 & 0.168 \\
\hline P Reduce income differences or not & -0.850 & -0.419 & -0.454 & -0.126 & 0.380 \\
\hline $\begin{array}{l}\text { P In order to maintain the EURO, Germany should transfer money to poorer } \\
\text { countries }\end{array}$ & 0.529 & -0.235 & -0.0662 & -0.0965 & -0.426 \\
\hline P! Minimal wages should be increased to 10 EUR or they should be abolished & 0.230 & $2.371^{*}$ & -0.363 & 0.595 & 0.788 \\
\hline P Deregulate the job market or keep current regulations & -1.281 & 0.0793 & -0.184 & -0.165 & 0.284 \\
\hline P Building more wind turbines or not & -0.951 & -0.712 & -0.865 & 0.538 & -0.213 \\
\hline P Diesel cars should be banned or not & 0.418 & 1.589 & 0.532 & 0.184 & 0.343 \\
\hline P Foreigners should adapt to national culture or not & $0.932^{*}$ & 1.625 & -0.175 & 0.703 & 0.249 \\
\hline P Repeal gay marriages or keep them & $-2.270^{* *}$ & -0.357 & -0.141 & -0.715 & 0.236 \\
\hline P Introduce possibilities for binding referenda or not & 0.369 & $1.581^{*}$ & 0.246 & -0.293 & -0.342 \\
\hline Constant & $-2.210^{*}$ & $-9.101^{* *}$ & $-1.945^{*}$ & $-5.588^{* * *}$ & $-3.045^{* *}$ \\
\hline Observations & 946 & 902 & 722 & 947 & 791 \\
\hline Pseudo $R^{2}$ & 0.538 & 0.494 & 0.287 & 0.322 & 0.349 \\
\hline
\end{tabular}

$\mathrm{P}=$ positional issues, $\mathrm{V}=$ valence issues, ! denotes above-average aggregate issue saliency

${ }^{*} p<0.05,{ }^{* *} p<0.01,{ }^{* * *} p<0.001$ 
Italy

Table A4. Binary logistic models of joining a party, based on issue goal credibilities, with controls (excludes stable party voters)

\begin{tabular}{|c|c|c|c|c|c|c|c|}
\hline & FdI & FI & Lega & Leu & M5S & $\mathrm{PD}$ & $+\mathrm{EU}$ \\
\hline Rural/Urban (1-4=Urban) & -0.822 & $0.689^{*}$ & 0.218 & 0.0856 & 0.0973 & -0.692 & -0.265 \\
\hline Sex $(1=$ Woman $)$ & $1.907^{*}$ & 1.089 & 0.110 & -0.0401 & $-0.987^{*}$ & 0.995 & 0.291 \\
\hline Age class $(1-5=65+)$ & -0.739 & $-0.552^{*}$ & 0.249 & 0.110 & 0.0862 & 0.842 & -0.108 \\
\hline Education (1-3=Tertiary) & -1.346 & -0.479 & -0.534 & 0.533 & 0.309 & 0.190 & 0.596 \\
\hline Political interest (1-4=Very interested) & 1.233 & -0.0679 & -0.126 & 0.335 & -0.0953 & 0.427 & -0.313 \\
\hline Living standards (1-7=Rich family) & 0.905 & -0.317 & -0.0260 & -0.858 & -0.314 & -0.899 & -0.594 \\
\hline Party closeness (0-3=Very close) & $3.133^{* * *}$ & $2.289^{* * *}$ & $2.515^{* * *}$ & $3.867^{* * *}$ & $2.120^{* * *}$ & $3.542^{* * *}$ & $2.198^{* * *}$ \\
\hline V! To fight unemployment & $5.207^{* * *}$ & 1.478 & -0.352 & 0.146 & 0.328 & $3.819^{*}$ & 0.302 \\
\hline V! To fight corruption & 0.351 & 0.272 & $1.235^{*}$ & $2.554^{*}$ & 0.354 & $-4.315^{*}$ & -1.878 \\
\hline V! Support economic growth & -1.386 & -0.565 & -0.460 & -0.0200 & -0.264 & $3.562^{*}$ & -0.0115 \\
\hline $\mathrm{V}$ ! To protect $<$ COUNTRY $>$ against terrorist attack & 0.380 & -0.117 & -0.121 & -2.441 & -0.340 & -1.811 & -0.239 \\
\hline V! To make $<$ COUNTRY $>$ count more in Europe & -2.157 & 0.283 & -0.602 & 1.571 & 0.322 & 0.939 & 0.861 \\
\hline V! To fight poverty & $-4.601^{*}$ & -0.772 & -0.210 & -1.620 & 0.360 & -1.476 & 0.520 \\
\hline V! To Fight crime and keep our communities safe & 1.811 & -0.885 & 0.872 & 1.088 & 0.621 & 0.409 & -2.361 \\
\hline V! To reduce costs of politics & 0.293 & $2.687^{* *}$ & -0.299 & -0.689 & -0.0445 & -0.00203 & -0.0686 \\
\hline V! To improve NHS & 0.195 & $2.002^{*}$ & -0.392 & 1.165 & $-1.547^{*}$ & 1.094 & 1.541 \\
\hline $\mathrm{V}$ ! To protect the environment & -0.984 & -0.133 & 0.852 & 1.092 & -0.658 & -0.232 & $2.496^{* *}$ \\
\hline $\mathrm{V}$ ! Improve the quality of education & $3.529^{* *}$ & -0.270 & 0.0908 & -0.904 & $1.827^{* *}$ & 1.156 & $1.829^{*}$ \\
\hline V! Renovate Italian politics & 1.179 & -0.0417 & 0.385 & 1.698 & $1.349^{*}$ & 1.570 & 1.130 \\
\hline P Reduce income differences or not & 0.558 & -0.377 & -0.225 & -1.373 & -0.903 & 0.496 & -1.513 \\
\hline P Increase freedom of enterprises or not & 1.139 & 0.274 & -0.163 & 0.642 & 0.209 & -1.748 & 0.227 \\
\hline P! Maintain actual law on pension age or reduce pension age & -3.610 & 1.171 & 0.527 & -2.591 & 0.0259 & 1.607 & 0.291 \\
\hline P Abolish university tuition fees or not & 2.222 & -0.712 & 0.245 & $2.174^{*}$ & 0.974 & -2.919 & 1.657 \\
\hline P! Maintain actual tax progressivity or introduce flat tax & -1.120 & -0.191 & 0.711 & -0.651 & 0.407 & 0.822 & 0.915 \\
\hline P Do not introduce minimum wage or introduce it & 1.762 & 1.149 & -0.520 & -0.543 & 0.472 & -2.101 & 0.189 \\
\hline $\mathrm{P}$ Introduce a citizenship income or not & $-4.017^{*}$ & -0.263 & -0.285 & -0.00337 & 0.857 & -0.475 & -0.627 \\
\hline P! Increase fight against tax evasion or not & 0.674 & -1.069 & 0.408 & $-3.261^{*}$ & -0.0686 & 2.101 & -0.845 \\
\hline P Increase economic benefit for families with children or not & -1.634 & $1.712^{*}$ & 0.600 & 1.067 & -0.368 & -0.642 & -0.285 \\
\hline P Limit or encourage economic globalization & 0.700 & -0.564 & -0.0939 & 1.413 & 1.110 & 2.539 & -1.139 \\
\hline P Stay or leave the Euro & 1.856 & -0.223 & $1.251^{*}$ & 2.454 & 0.663 & -1.577 & 2.124 \\
\hline P! Stay or leave the UE & 0.861 & 0.179 & -0.536 & 1.499 & -0.813 & $4.413^{*}$ & 0.239 \\
\hline P Make political economic of UE more flexible or not & 0.891 & 0.770 & 0.172 & 1.145 & 0.448 & -0.0911 & $-2.317^{*}$ \\
\hline P Ius soli or not & 0.917 & $-2.361^{*}$ & -0.230 & 1.060 & 0.699 & 1.656 & 1.404 \\
\hline P Reduce access to welfare benefits for immigrants or not & -0.371 & -0.0130 & 0.303 & -2.198 & 1.224 & $-2.939^{*}$ & -0.752 \\
\hline P! Continue to accept refugees or limit refugees & 1.433 & 0.263 & $1.603^{*}$ & 1.091 & 0.149 & 2.565 & 1.274 \\
\hline P Maintain biological testament or abolish it & -4.039 & -0.576 & -0.422 & -0.492 & -0.719 & -0.0463 & -1.883 \\
\hline P Abolish same-sex unions or maintain them & 0.776 & 0.144 & -0.0793 & 1.411 & -0.707 & 1.892 & -0.00478 \\
\hline P Legalize soft drugs or not & -1.105 & 0.406 & -0.714 & -1.499 & -0.811 & -0.465 & 1.639 \\
\hline P! Maintain vaccines compulsory or not & -1.325 & 1.117 & 0.592 & 0.521 & 0.607 & -3.101 & 0.614 \\
\hline P Legalize prostitution or not & 1.011 & -0.640 & 0.706 & 0.134 & 0.654 & -3.677 & 0.337 \\
\hline P Decriminalize excess of legitimate defense or not & 1.855 & 0.693 & 0.158 & 0.280 & -0.787 & 2.216 & 0.260 \\
\hline Constant & $-10.68^{* *}$ & $-4.647^{*}$ & $-5.944^{* * *}$ & $-6.876^{*}$ & $-3.921^{* *}$ & $-9.404^{*}$ & $-4.928^{*}$ \\
\hline Observations & 979 & 892 & 940 & 951 & 786 & 716 & 997 \\
\hline Pseudo $R^{2}$ & 0.693 & 0.584 & 0.605 & 0.712 & 0.617 & 0.760 & 0.675 \\
\hline
\end{tabular}

$p$-values in parentheses

$\mathrm{P}=$ positional issues, $\mathrm{V}=$ valence issues, ! denotes above-average aggregate issue saliency

${ }^{*} p<0.05,{ }^{* *} p<0.01,{ }^{* * *} p<0.001$ 


\section{Netherlands}

Table A5. Binary logistic models of joining a party, based on issue goal credibilities, with controls (excludes stable party voters)

\begin{tabular}{|c|c|c|c|c|c|c|c|c|c|c|}
\hline & 50 plus & $\mathrm{CDA}$ & $\mathrm{CU}$ & D66 & GL & Pvda & PvdD & PVV & SP & VVD \\
\hline ural/Urban (1-4= & 17 & 0.158 & -0.229 & 0.202 & -0.214 & 0.401 & -0.00969 & -0.0430 & 0.190 & -0.406 \\
\hline ex (1=Woman) & 0.0638 & 0.257 & 0.696 & -0.297 & $0.605^{*}$ & 1.120 & 0.203 & 0.113 & 0.0514 & 0.0138 \\
\hline Age class $(1-5=65+)$ & $0.286^{*}$ & -0.0855 & -0.0799 & $-0.346^{* *}$ & $-0.302^{* *}$ & -0.135 & $-0.614^{* * *}$ & -0.0427 & -0.196 & $-0.610^{* *}$ \\
\hline Education (1-3=Tertiary) & 0.302 & 0.131 & 0.134 & 0.142 & 0.132 & 0.545 & -0.189 & -0.102 & $-0.691^{* * *}$ & 0.313 \\
\hline olitical interest (1-4=Very interested) & $-0.696^{* *}$ & -0.142 & -0.446 & -0.106 & -0.207 & -0.449 & -0.427 & -0.349 & $-0.400^{*}$ & 0.105 \\
\hline ving standards (1-7=Rich family) & 0.0709 & 0.126 & -0.0412 & -0.00164 & -0.162 & $-0.602^{*}$ & -0.189 & $-0.273^{*}$ & 0.183 & 0.104 \\
\hline Party closeness $(0-3=$ Very close $)$ & $1.650^{* * *}$ & $1.579^{* * *}$ & $1.827^{* * *}$ & $1.603^{* * *}$ & $1.672^{* * *}$ & 2.127 & $1.593^{* * *}$ & $1.380^{* * *}$ & $1.950^{* * *}$ & $1.676^{* * *}$ \\
\hline$V$ ! Protect the Netherlands against terrorist attacks & -0.255 & -0.136 & -0.747 & -0.157 & -0.217 & $-2.669^{*}$ & 0.0855 & 0.107 & $0.883^{*}$ & -0.231 \\
\hline$V$ ! Maintain the current economic growth & 0.125 & 0.152 & 0.292 & $0.726^{*}$ & -0.654 & $2.310^{* *}$ & -0.255 & 0.537 & 0.324 & 0.601 \\
\hline V! Further reduce unemployment & -0.289 & $1.182^{* *}$ & 0.238 & 0.621 & 0.224 & -1.315 & -0.830 & -0.420 & 0.0248 & 0.229 \\
\hline V! Fight environmental pollution & 0.459 & $-1.037^{*}$ & 1.561 & 0.151 & $0.999^{* *}$ & -1.773 & -0.0483 & -0.346 & -0.226 & -1.087 \\
\hline $\mathrm{V}$ ! Improve care for the elderly and the disabled & $0.820^{*}$ & 0.107 & -0.0261 & 0.608 & $-0.700^{*}$ & -1.085 & -0.420 & 0.377 & 0.224 & $1.411^{*}$ \\
\hline P Reduce income differences or not & $1.907^{* * *}$ & $1.036^{*}$ & 1.738 & $2.054^{* * *}$ & $1.272^{* * *}$ & -0.458 & $2.286^{* * *}$ & $1.470^{* * *}$ & $2.043^{* * *}$ & $2.156^{* * *}$ \\
\hline ! Fixed term contracts or not & 0.445 & 0.637 & 0.990 & 0.551 & -0.0998 & $1.815^{*}$ & 0.182 & 0.227 & -0.578 & 0.418 \\
\hline Maintain or restrict welfare benefits & -1.095 & 0.648 & 0.750 & 0.0856 & 0.157 & $2.234^{* *}$ & 1.006 & 0.112 & 0.353 & -0.930 \\
\hline ! Maintain or reduce the number of refugees & $-1.771^{*}$ & 0.580 & 0.0416 & 0.506 & 0.694 & -0.612 & -0.995 & 0.9 & 0.315 & 0.743 \\
\hline $\begin{array}{l}\text { Completely close the Dutch borders to immigrants } \\
\text { not }\end{array}$ & 0.333 & 0583 & 0676 & -0.0699 & 0.0339 & 0482 & 0736 & 0. & 01 & 0.905 \\
\hline P! Foreigners can preserve their own culture or not & 0.536 & -0.307 & 0.565 & -0.817 & 0.395 & $1.798^{*}$ & -0.240 & 0.174 & -0.787 & 0.707 \\
\hline P! Abolish the deductible in health insurance or not & -0.0790 & -0.0981 & -1.450 & 0.227 & $0.744^{*}$ & -0.679 & 0.0758 & 0.234 & 0.256 & -0.0227 \\
\hline ! Reduce the pension age to 65 or not & $1.161^{* *}$ & 0.435 & 0.907 & $-0.877^{*}$ & 0.0905 & -0.0359 & 0.561 & 0.603 & 0.666 & -0.421 \\
\hline A Allow elderly to be assisted in ending their life or not & 0.00860 & 0.0139 & $2.614^{* *}$ & 0.419 & 0.379 & -1.578 & 0.160 & -0.564 & -0.0682 & -0.148 \\
\hline P Maintain the current weed policy or legalise it & 0.406 & 0.411 & -0.602 & -0.270 & 0.0594 & -0.220 & -0.283 & 0.112 & -0.611 & 0.0764 \\
\hline P Abolish or maintain the student loans & 0.165 & 0.345 & -0.798 & -0.0188 & 0.0316 & 1.241 & -1.943 & & 0.0360 & 0.878 \\
\hline P Allow binding referenda or not & -0.475 & -0.359 & 0.333 & -0.00787 & -0.126 & 0.827 & $1.527^{*}$ & 0.241 & -0.0415 & -0.293 \\
\hline P Increase defense spending or not & 0.153 & 0.0332 & -0.966 & 0.302 & $0.868^{*}$ & 0.989 & 1.441 & -0.185 & 0.151 & -1.047 \\
\hline P! Leave the EU or not & 0.149 & -0.161 & -2.491 & -0.0548 & $1.018^{* *}$ & -0.142 & 0.154 & $0.816^{*}$ & -0.846 & 0.0703 \\
\hline P Increase tax on meat or not & 0.957 & 0.516 & 0.124 & $-1.073^{*}$ & 0.131 & -0.252 & $1.112^{*}$ & -0.564 & 0.201 & -0.0315 \\
\hline Constant & $-5.557^{* * *}$ & $-5.431^{* * *}$ & $-5.180^{*}$ & $-3.914^{* * *}$ & $-3.291^{* * *}$ & $-5.814^{* *}$ & -1.539 & $-2.827^{* * *}$ & $-2.870^{* * *}$ & $-4.407^{* *}$ \\
\hline Observation & 1947 & 1892 & 1941 & 1893 & 1920 & 1732 & 1934 & 1670 & 1740 & 1725 \\
\hline Pseudo $R^{2}$ & 0.405 & 0.379 & 0.522 & 0.441 & 0.504 & 0.391 & 0.448 & 0.566 & 0.453 & 0.414 \\
\hline
\end{tabular}

$\mathrm{P}=$ positional issues, $\mathrm{V}=$ valence issues, ! denotes above-average aggregate issue saliency ${ }^{*} p<0.05,{ }^{* *} p<0.01,{ }^{* * *} p<0.001$ 


\section{United Kingdom}

Table A6. Binary logistic models of joining a party, based on issue goal credibilities, with controls (excludes stable party voters)

\begin{tabular}{|c|c|c|c|c|}
\hline & Cons & Lab & LibDem & UKIP \\
\hline Rural/Urban (1-4=Urban) & -0.152 & $0.311^{*}$ & $-0.419^{*}$ & -0.530 \\
\hline Sex $(1=$ Woman $)$ & 0.492 & -0.255 & 0.668 & 0.338 \\
\hline Age class $(1-5=65+)$ & 0.172 & -0.241 & -0.247 & $-0.451^{*}$ \\
\hline Education (1-3=Tertiary) & $0.361^{*}$ & 0.0742 & 0.246 & -0.648 \\
\hline Political interest (1-4=Very interested) & -0.0413 & $-0.382^{*}$ & -0.168 & -0.199 \\
\hline Living standards (1-7=Rich family) & 0.00817 & -0.0620 & 0.256 & -0.332 \\
\hline Party closeness $(0-3=$ Very close $)$ & $1.319^{*}$ & $1.782^{* * *}$ & $1.418^{*}$ & 2.610 \\
\hline $\mathrm{V}$ ! Protect the UK from terrorist attacks & -0.157 & 0.501 & 0.330 & -1.020 \\
\hline V! Reduce unemployment & 0.640 & -0.472 & -0.510 & 0.497 \\
\hline V! Improve the NHS & 0.111 & 0.747 & 0.287 & 0.644 \\
\hline $\mathrm{V}$ Protect the environment & 0.378 & -0.176 & 1.037 & -3.147 \\
\hline V! Improve the quality of schools & 0.0851 & 0.0861 & $1.970^{* *}$ & -0.519 \\
\hline V! Control immigration & 0.337 & -0.399 & 0.00492 & 0.283 \\
\hline V! Fight crime and keep our communities safe & -0.277 & 0.601 & $-1.769^{*}$ & -0.490 \\
\hline V! Protect pensions & 0.213 & -0.0602 & 0.722 & $1.926^{*}$ \\
\hline V! Boost economic growth & -0.247 & -0.419 & 0.876 & 0.923 \\
\hline V! Provide leadership for the country & $1.279^{* * *}$ & $1.074^{* *}$ & 0.187 & 1.280 \\
\hline $\mathrm{P}$ ! Stay in the EU or leave it & $1.203^{* *}$ & 0.588 & $1.577^{*}$ & $1.259^{*}$ \\
\hline P! Taxes or social services & 0.699 & $1.113^{* *}$ & 0.0551 & 0.402 \\
\hline P Maintain or dismantle Britain's nuclear weapons & 0.518 & 0.339 & -1.277 & 0.400 \\
\hline P Expand or limit the provision of grammar schools & 0.462 & 0.169 & 0.376 & 0.0353 \\
\hline P Ban or allow Islamic veil in public spaces & -0.376 & -0.212 & -1.038 & 0.539 \\
\hline $\mathrm{P}$ ! End or allow freedom of movement from the EU & 0.355 & 0.259 & 0.320 & $1.484^{*}$ \\
\hline P Public or private money to build affordable homes & -0.248 & 0.351 & $1.242^{*}$ & -0.474 \\
\hline P Increase the minimum wage or not & 0.0936 & 0.281 & -0.644 & 0.219 \\
\hline P! Remain or leave the European Single Market & $0.900^{*}$ & -0.125 & 0.694 & 0.261 \\
\hline P Reduce income differences or not & 0.106 & -0.251 & -0.802 & -0.542 \\
\hline P Allow Scottish referendum on independence or not & -0.0159 & -0.238 & $1.279^{*}$ & 0.387 \\
\hline P Maintain or scrap the cost of university tuition fees & -0.365 & 0.620 & -0.376 & -0.219 \\
\hline P Allow or prohibit the use of fracking & -0.302 & -0.273 & -0.854 & -0.612 \\
\hline P Ban or maintain zero hours contracts & -0.0141 & -0.445 & -0.347 & 0.823 \\
\hline P! Restrict or maintain welfare benefits for immigrants & -0.133 & -0.0322 & -0.235 & -0.441 \\
\hline P Foreigners should fully adapt to British culture or not & -0.0546 & 0.575 & -0.584 & 0.0647 \\
\hline P Keep or repeal gay marriages & -0.521 & -0.491 & 0.747 & -0.638 \\
\hline P Nationalize Britain's railways or not & -0.0555 & -0.0262 & 0.845 & 0.0244 \\
\hline Constant & $-4.767^{* * *}$ & $-2.674^{* *}$ & $-4.820^{* * *}$ & -0.526 \\
\hline Observations & 665 & 687 & 888 & 843 \\
\hline Pseudo $R^{2}$ & 0.406 & 0.350 & 0.390 & 0.438 \\
\hline
\end{tabular}

$\mathrm{P}=$ positional issues, $\mathrm{V}=$ valence issues, $!$ denotes above-average aggregate issue saliency ${ }^{*} p<0.05,{ }^{* *} p<0.01,{ }^{* * *} p<0.001$ 
Table A7. Summary of significant issue effects on vote inflows for parties and candidates

\begin{tabular}{|c|c|c|c|c|}
\hline & \multirow{2}{*}{$\begin{array}{l}\text { Total parties affected } \\
\text { (of } 38 \text { parties) }\end{array}$} & \multicolumn{3}{|c|}{ Significant issue effects on vote inflows } \\
\hline & & Conservative & Progressive & "Valence" \\
\hline \multicolumn{5}{|l|}{ Economic issues: } \\
\hline Welfare & 21 & 0 & 7 & 16 \\
\hline Economic policy & 19 & 0 & 11 & 4 \\
\hline Job market & 9 & 1 & 1 & 6 \\
\hline \multicolumn{5}{|l|}{ Cultural issues: } \\
\hline EU & 13 & 8 & 6 & 2 \\
\hline Immigration & 9 & 9 & 1 & 0 \\
\hline Institutions & 9 & 1 & 3 & 4 \\
\hline Environment & 7 & 0 & 2 & 3 \\
\hline Individual liberties & 5 & 1 & 2 & 2 \\
\hline Security & 5 & 0 & 0 & 4 \\
\hline
\end{tabular}

